\title{
عصمة الأنبياء عند الأشاعرة في ضوء القرآن الكريم: نقد وتأصيل
}

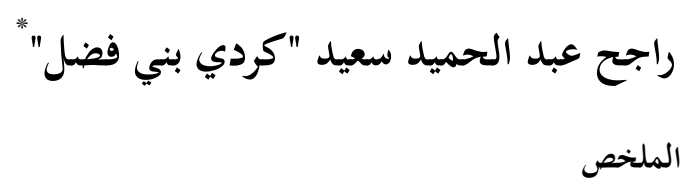

هذه دراسة نقدية أصولية في عصمة الأنبياء عند علماء الأشاعرة من أهل السنة في ضوء القرآن الكريم. فقد شكّلت هذه القضية مشكلة للبحث عند هؤلاء العلماء، مـن خلال تفسير ما ورد في قصص الأنبياء، مما له علاقة بالألفاظ والعبارات التي قد توهم في نظرهم التعارض مع العصمة، و قدّموا فهماً وتأويلاً حافظوا به على العصمة في نظرهم، كما نقلوا الإسرائيليات واضطروا لبحثها. وكان لهم فهم في تفسير آيات العصمة، مارسوا فيه منطق الدفاع بالرد على المخالفين في العصمة، وولَّد هذا الفهم إشكالات عند اعتماد المرجعية القرآنية. وقد حاول الباحث استنباط قواعد من القرآن الكريم في عرضه لقصص الأنبياء. وانتهى البحث إلى ضرورة بحث عصمة الأنبياء مع الالتزام بقواعد القرآن الكريم في فهمها.

\section{كلمات مفتاحية: عصمة الأنبياء، الأشاعرة، قواعد العصمة، الإسرائيليات، قصص الأنبياء، قواعد قرآنية.}

\section{The Prophets' Infallibility as Understood by the Ash'arites: A Critique and Foundation Building in the Light of the Noble Quran}

\begin{abstract}
This study provides a critique and a foundation building of the infallibility of the Prophets as perceived by the Sunni Ash'arite scholars. The study takes the Qur'an as the basis for addressing this issue. For the Ash'arites, this theme has presented a problem in their effort to interpret the Qur'anic narrative about the Prophets, especially those narratives that present statements and expressions that may cause a conflict with infallibility. Since the Ash'arites have included stories from the Israelite sources, they found themselves compelled to discuss these stories. This understanding has yielded problems in interpretation when the Qur'anic authority is considered. The researcher attempts to identify Qur'anic principles in explaining the stories of the Prophets, and concludes with the need to re-address the issue of the Prophets' infallibility with a commitment to the Qur'anic principles.
\end{abstract}

Keywords: Prophets' infallibility, Ash'arites, Infallibility rules, Israelites, Stories of the Prophets, Qur'anic principles.

" دكتوراه في العقيدة، أستاذ مشارك في كلية الشريعة بالجامعة الأردنية، البريد الإلكتروني: Gmajeh47@Gom

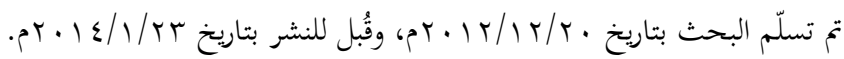


مقدمة:

تمثل قضية عصـمة الأنبيـاء أحسد المحاور الكبرى في ركن الإيمـان بالرُّسل، ذلك أهـا تندرج فيما يجبـ للأنبياء والرُّل، وما يجوز عليهم وما يستحيل في حقهم؛ لما لهم مـن دور في كوفم بشراً اصطفاهم الله تعالى لتبليغ وحيه إلى من بعثه إليهم، فوظيفتهم تقتضي

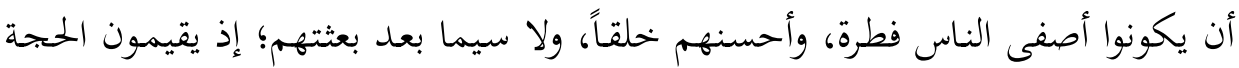
على الناس، وهم قدوة وأسوة حسنة لأتباعهم؛ فمنطقي عقلاً وشرعاً ألا يقعوا في ما ينفِّر الناس منهم، ويصرفهم عن دعواقهم.

وقد جاء القصص القـرآني في الأنبياء يعزز هذا الابجاه، ويجعل مـن قصصهم عبرة،

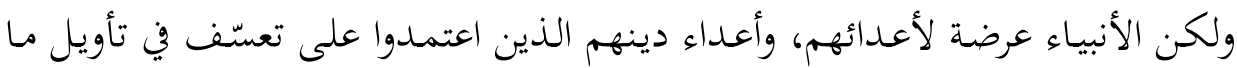

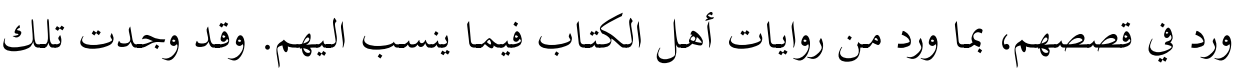
الروايات في كتب التفسير، وفق قواعد الأمانة في النقل في معرض تفسير قصص الأنبياء

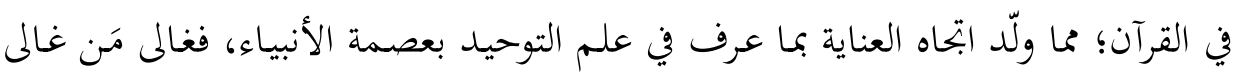
في هذه العصمة حتى كاد يخرجهم إلى قداسة تبعدهم عن البشرية، وتُّيل عليهم بحرد التفكير بالذنب أو المعصية.

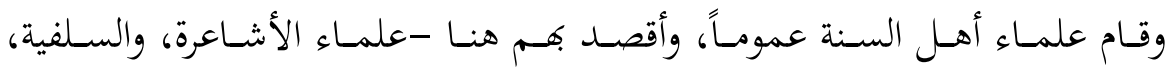

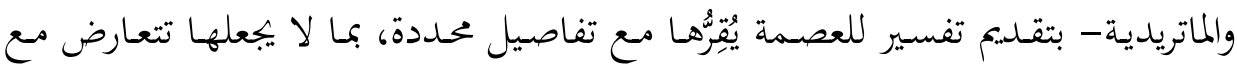

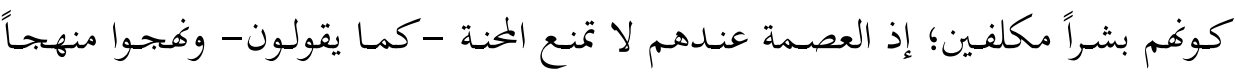

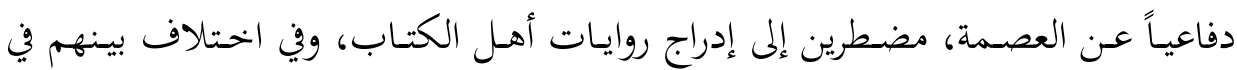

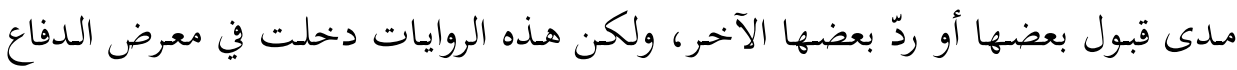

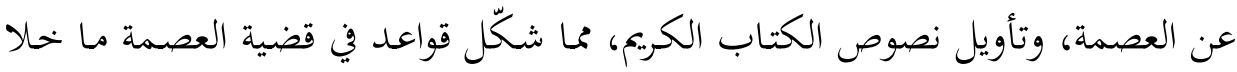

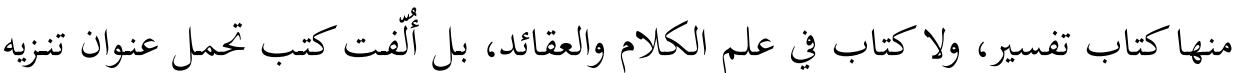
الأنبياء وعصمة الأنبياء، مثل: إثبات الحجة في بيان العصمة لأبي بكر محمد بن اللباد بن

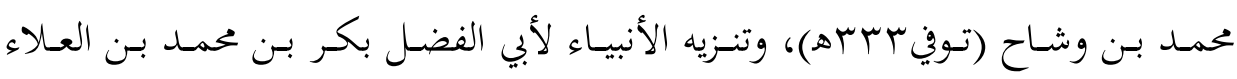

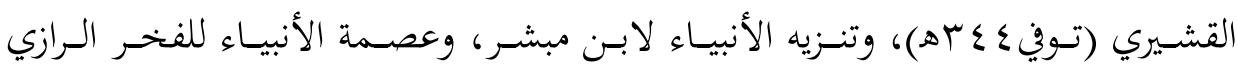




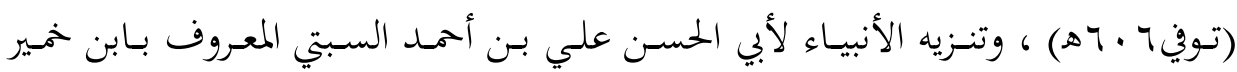

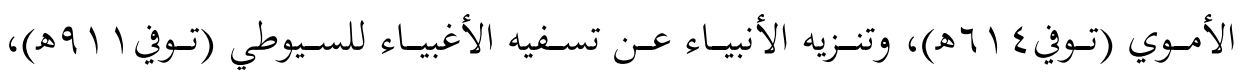

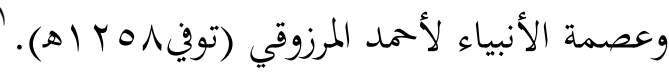

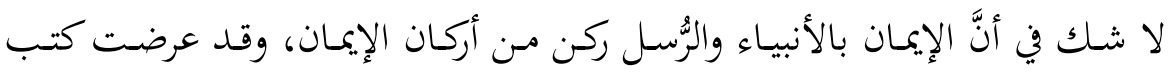

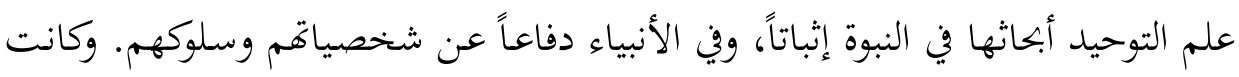

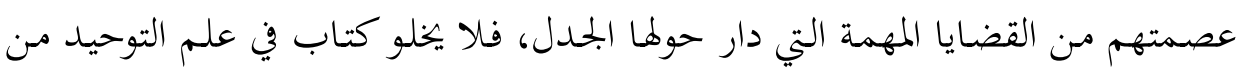

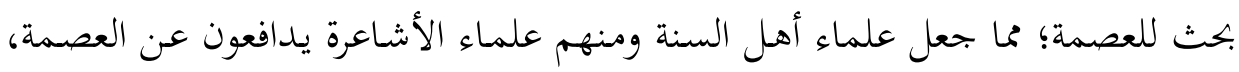

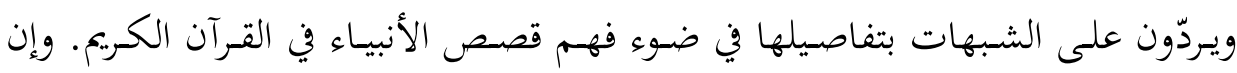

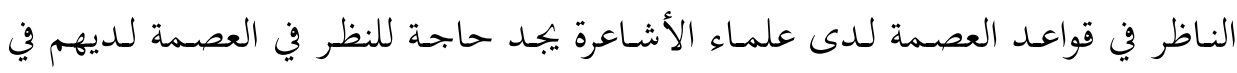
ضوء قواعد محددة في فهم القرآن الكريع.

وتمدف هذه الدراسة إلى معرفة أهمية العصمة، وأدلتها عند علماء الأشاعرة من أهل

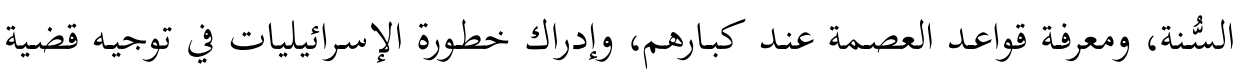

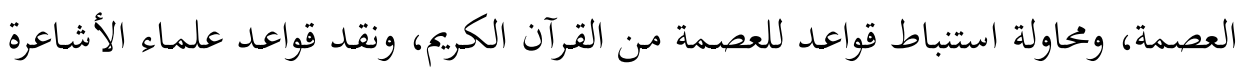
في العصمة في ضوء هذه القواعد.

ويوظف البحث ثلاثة مناهج؛ أولها المنهج التاريخي، الذي يقوم بتتبع معالجات قضية

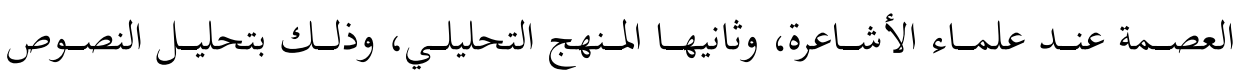

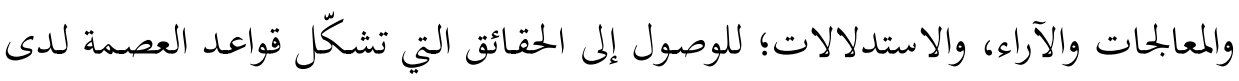

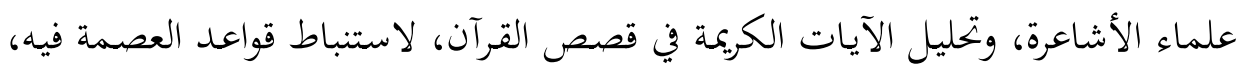

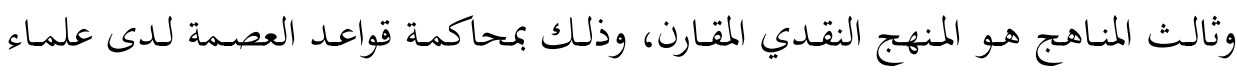
الأشاعرة، وفق قواعد القرآن الكريم.

' الذهبي، محمد أممد بن عثمان. سير أعلام النبلاء، تحقيق: لجنة بإشراف شعيب الأرناؤوط، بيروت: مؤسسة

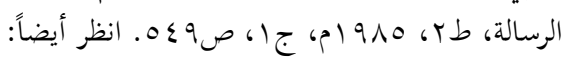

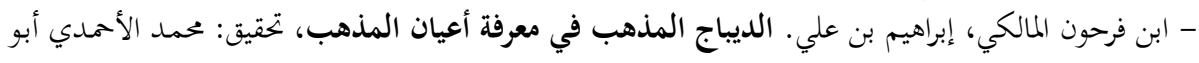

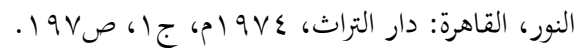

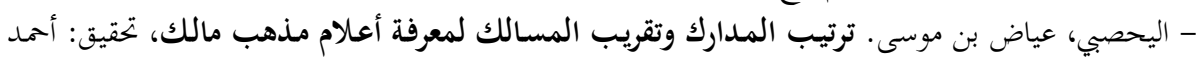

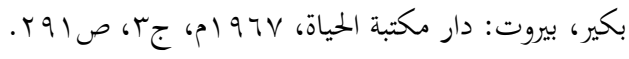




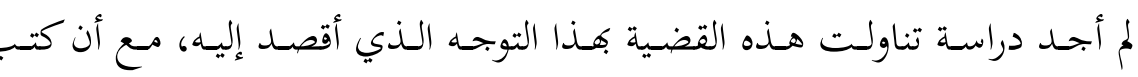

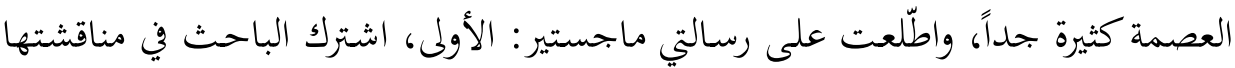

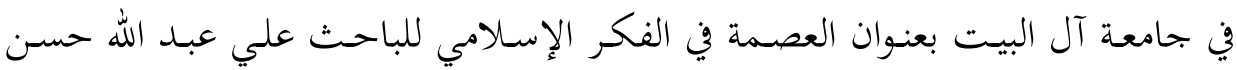

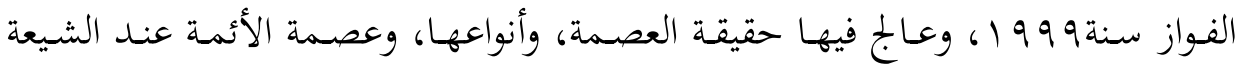
الإماميـة وعلاقتها بالإمامـة عنــهـم. والرسـالة الثانيـة، رسـالة ماجسـتير بعنـوان مفهـوم العصمة في اليهودية، والمسيحية، وموقف الإسلام منها، والرسالة مـن إعداد الباحثة هبة

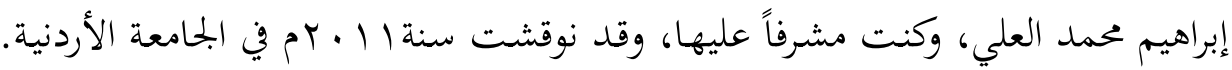
وقد تناولت فيها الباحثة العصمة عند اليهودية والمسيحية، مـن خلالال نصوص كتب ولب أهل

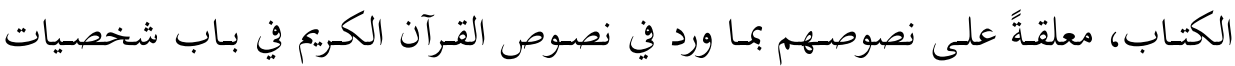
الأنبياء في القرآن، خلافاً لنصوص أهل الكتاب التي ليس فيها عصمة للأنبياء والرسل.

\section{أولاً: العصمة عند علماء الأشاعرة من أهل السُّنة؟}

\section{I ـ موقفان في بحث العصمة:}

هنـاك موقفـان يوضـحان بحـث العصـمة عنـــ علمـاء التوحيــ وهمـا: الموقف الأول: موقف قَبْلي، وهو عام متفق عليه، وبحمع عليه، وهو الموقف الإجمالي القائل بأن للأنبياء

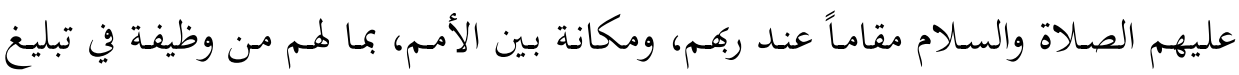

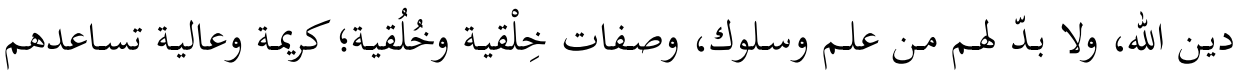

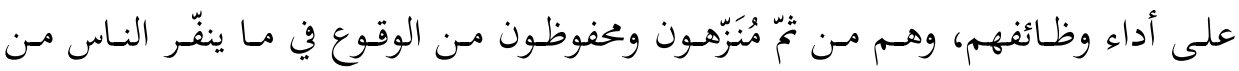

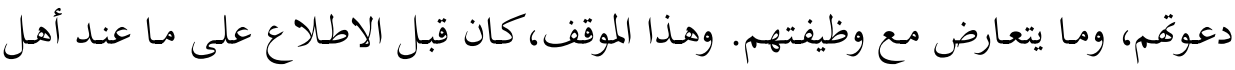

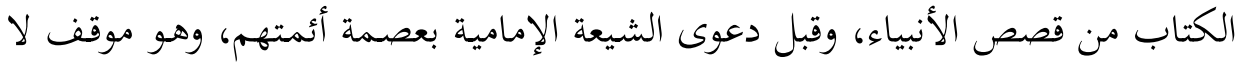

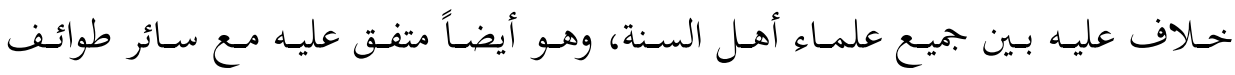
المسلمين.

الموقف الثاني: موقف بَعْدي، وذلك بعـد القول بعصمة الأئمهة عند الشيعة، فِإن

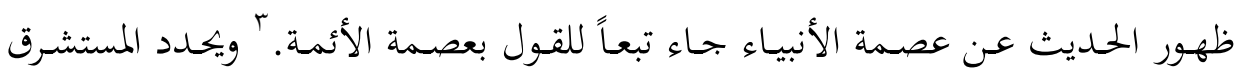




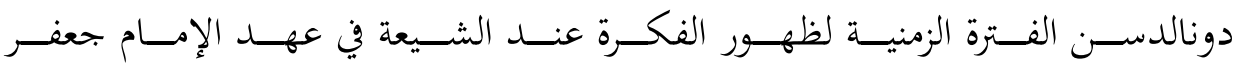

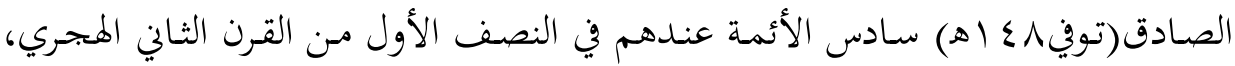

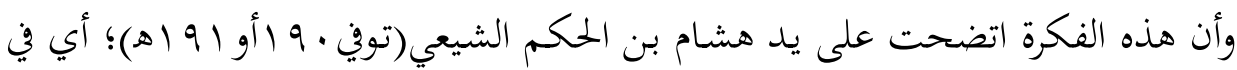

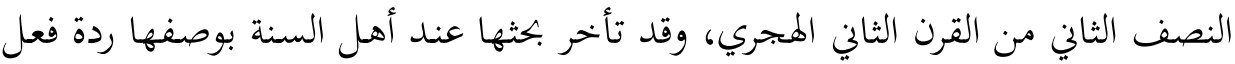

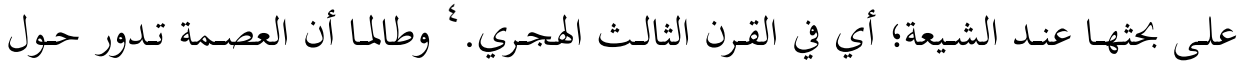

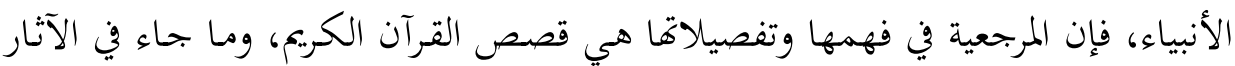

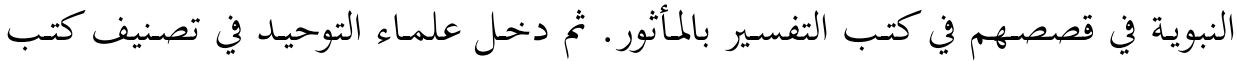
متخصصة في العصمة، وفي ثنايا بكثهم للنبوة في موسوعاهم الكلامية.

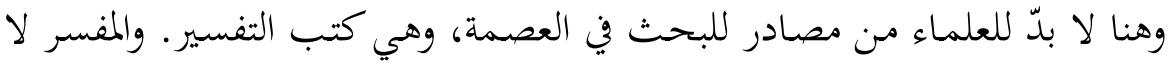

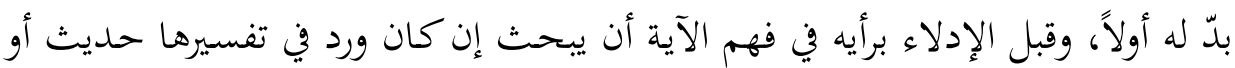

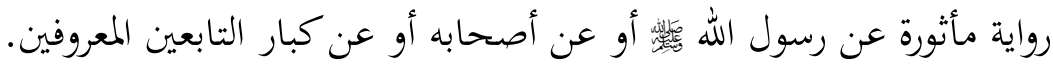
وهذا ما وقع تماماً في أقدم الكتب التي تمثل هذا المنهج، وهو تفسير أبي جعفر محمد

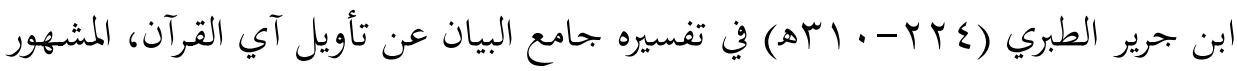

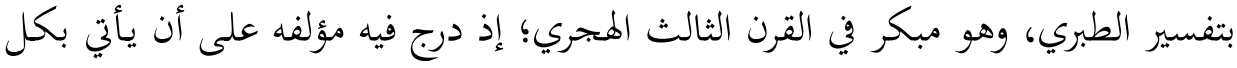

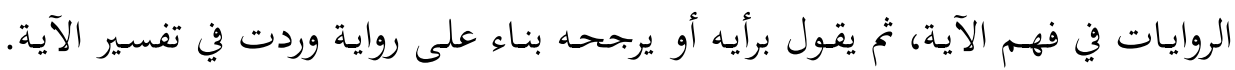

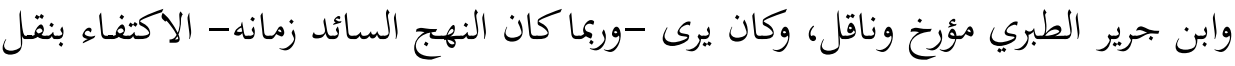

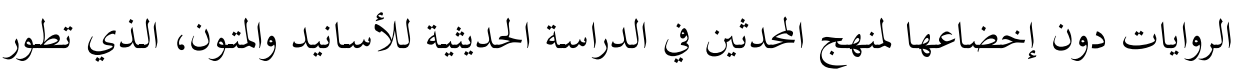
لاحقاً.

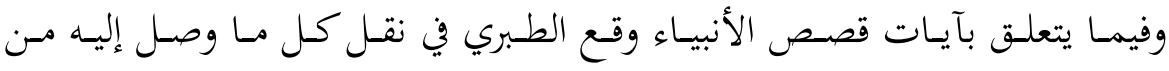

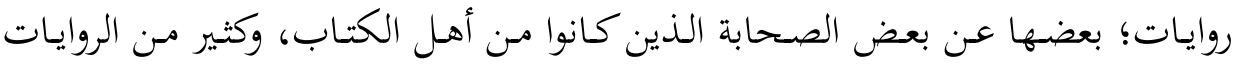

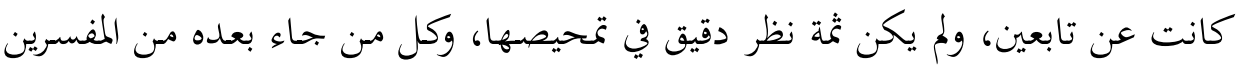

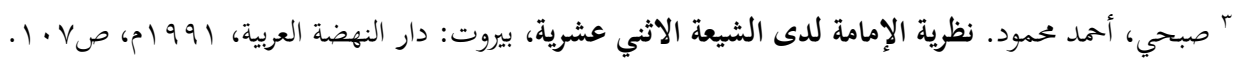

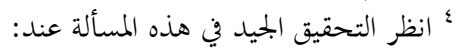
- الفواز، علي عبد الله. العصمة في الفكر الإسلامي، (رسالة ماجستير، جامعة آل البيت، كلية الدراسات 
كـان يرجـع إليـه في نقـل هـذه الروايـات عنـه. وكـان علمـاء التوحيـــ يرجعـون إلى تلـك

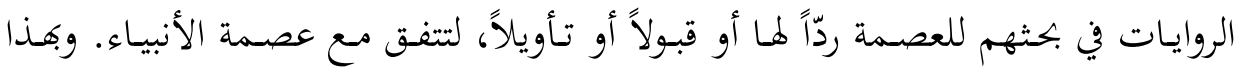
أصبحت لدينا مواقف في تعريف العصمة وتأويل الآيـات لتوافق مفهومها، والاستدلال عليها، والردّ على المخالف لها.

\section{Y ب ضرورة العصمة وأدلنها عندهم:}

اشتغلت المدرسـة الأشعرية مـن أهـل السُّنة بقضية العصـمة مع سـائر مـدارس أهـل السُنة من سلفية وماتريدية، مؤكدةً القضايا الآتية: - الأنبيـاء معصومون عمّا يتنـاقض مه وظيفتهم في تبليخ ديـن الله، وعـدّهم قـدوة للمكلفين.

- عصمتهم لا تحول دون بشريتهم، لصلاحيتهم للاقتداء من قبل المكلفين. - وقوع بعضض الـزّلات مـنهم، مــا ورد في القـرآن الكـريم، وممـا يـوهم ظـاهره بعـدم

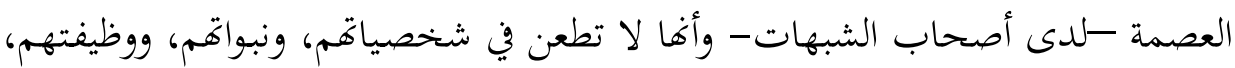
تأكيداً لبشريتهم.

وبعد الدراسة لكتب علم الكالام، وتراث مدرسة الأشاعرة من أهل السنة في موضوع عصمة الأنبياء، يمكن الوصول إلى أهم آرائهم دون الدخول في تفاصيل المسائل ودقائقها

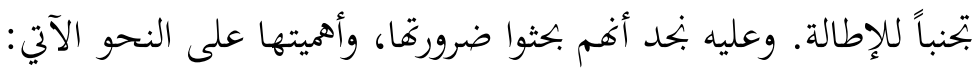

\section{أ. ضرورة العصمة للأنبياء:}

اتفقوا على ثبوت العصمة للأنبياء، وعلى ضرورتا بصفة عامة، مع اختلافهم في أي الأفعال تكون، ومتى تكون؟ هـل قبل البعثة أو بعدها؟ وهـل هي صغائر أو كبائر؟ وهـل هي على وجـه التعمُّد أو النسيان أو الخطأ أو مخالفـة الأولى؟ إلا أفها على كلى الأحسوال ثنابتة.

واستدلوا بالآيات التي تثبت العصمة؛ ذلك بأهم مصطفون، وأفهم أخيار، ويُخَْصون ومفلحون، ومن حزب الله، وأهم لو كانوا غير معصومين لوقعت أمور باطلة من كوفم 


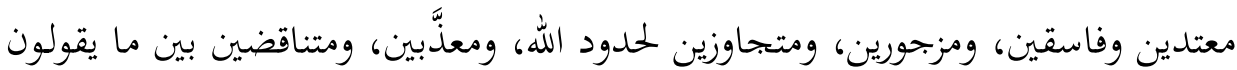

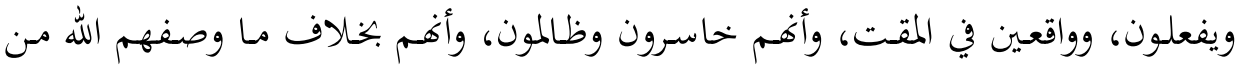

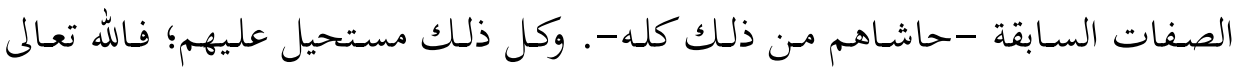

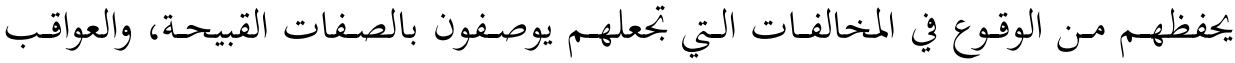
الوخيمة؛ إذ هم أنبياء الله، وسفراؤه إلى خلقه.

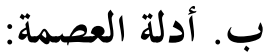

اتفقت كلمـت الأشاعرة على الاستدلال بالآيات التي تـل على وجـوب العصمة

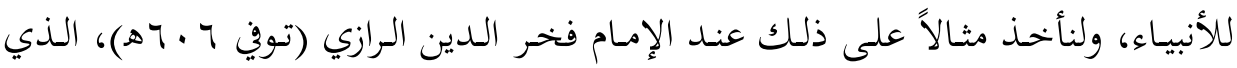

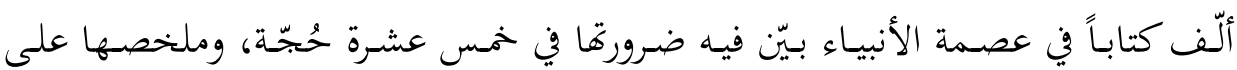
النحو الآتي:

- لو صدر الذنب عنهم لكان حالهم في استحقاق الذّم عاجلاً، والعقاب آجلاً

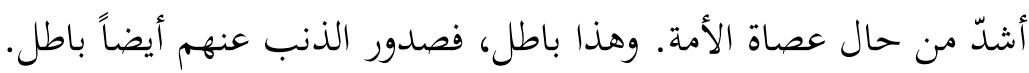

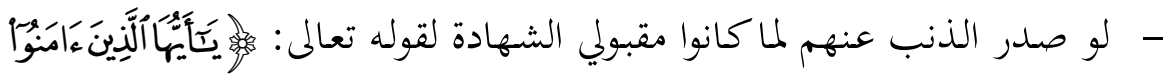

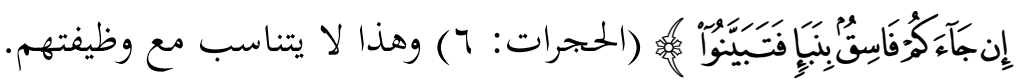

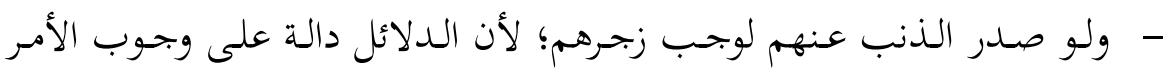

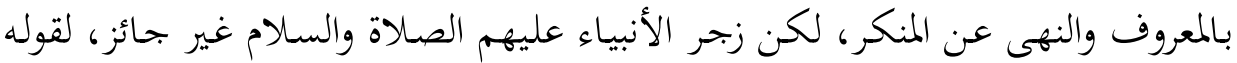

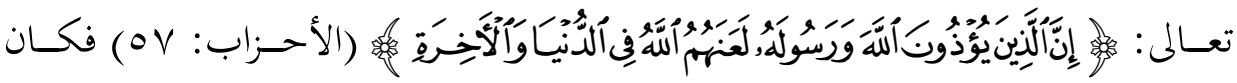
صدور الذنب عنهم ممتنعاً. - لو صدر الفسق عن محمد عليه الصلاة والسلام -مثلاً- لكنّا مأمورين بالاقتداء

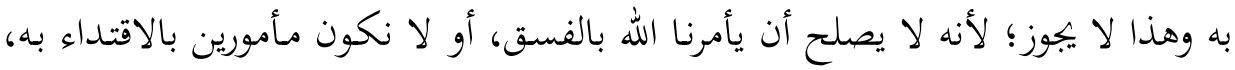

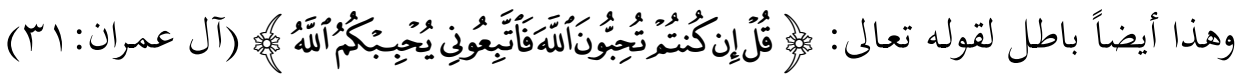

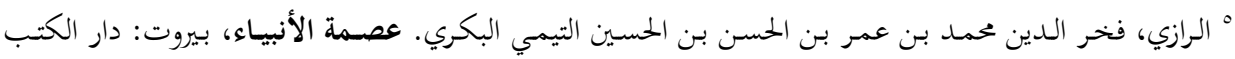

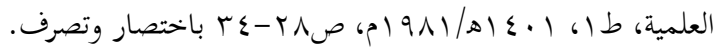




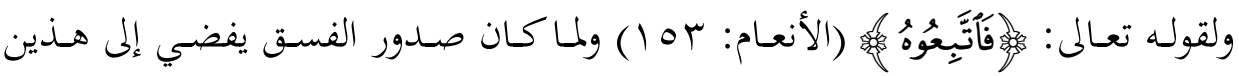
القسمين الباطلين كان صدور الفسق عنه محالاً. وهكذا كل الأنبياء والرسل الذين قال

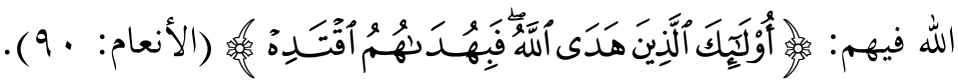
- لـو صـدرت المعصسية عـن الأنبيـاء علـيهم الصـلاة والسـلام لوجـبـ أن يكونـوا

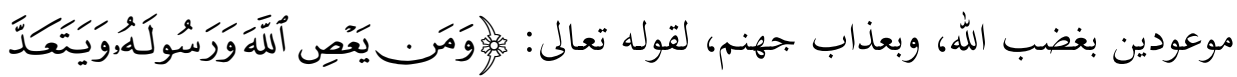

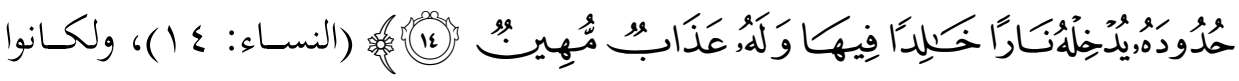

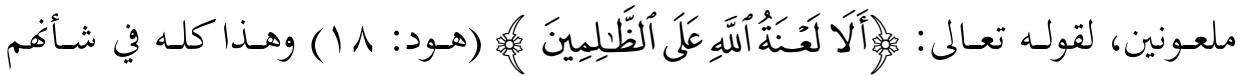
باطل وبإجماع الأمة؛ فكان صدور المعصية عنهم باطلاً. - - إهم كانوا يأمرون بالطاعات، وترك المعاصي، فلو تركوا الطاعة، وفعلوا المعصية

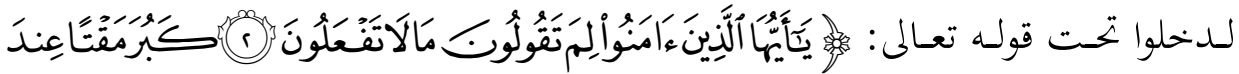

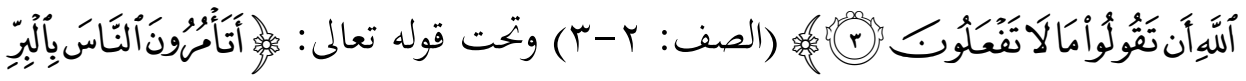

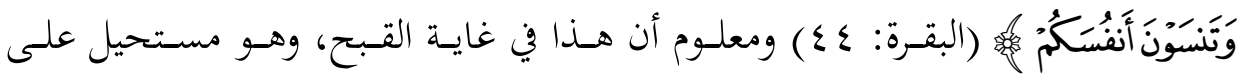
الأنبياء.

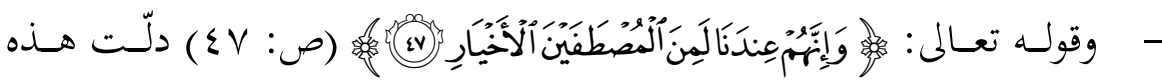

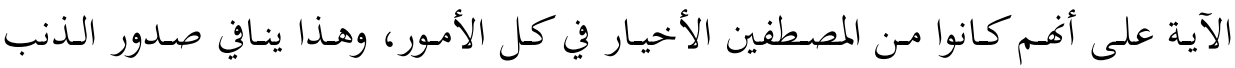
-

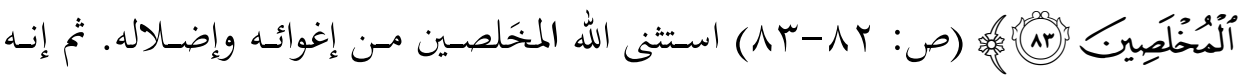
تعالى شهد على إبراهيم، وإسحاق، ويعقوب عليهم الصلاة والسالام أغهم من المُحخَصين،

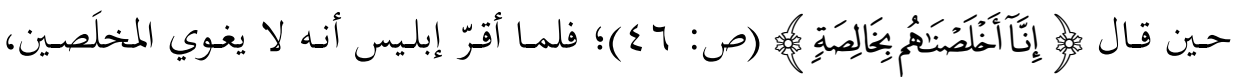

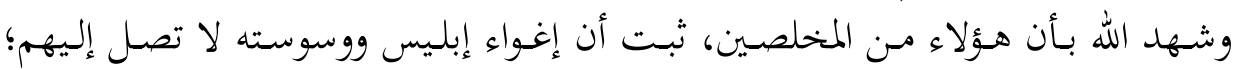
وذلك يوجب القطع بعدم صدور المعصية عنهم.

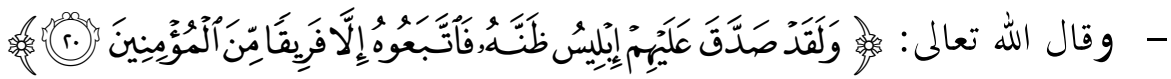

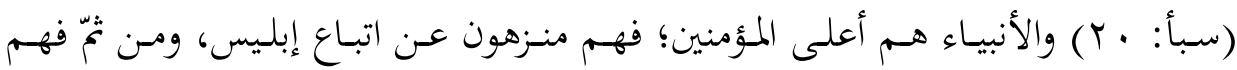




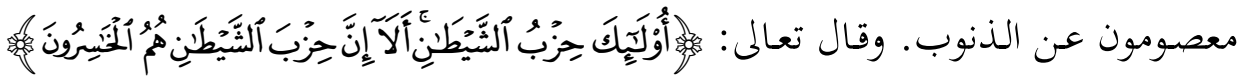

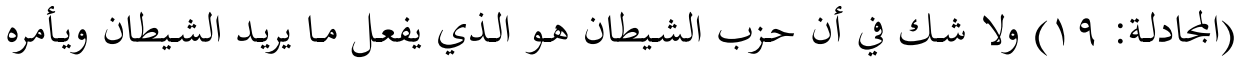

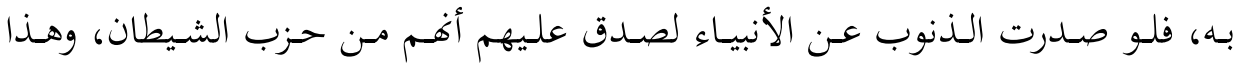
باطل.

- - إن الأنبياء أفضل من الملائكة، وثابت بالدلالة أن الملائكة مـا أقدموا على شيء

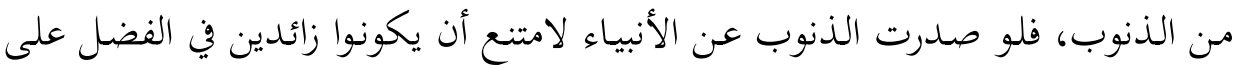

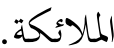

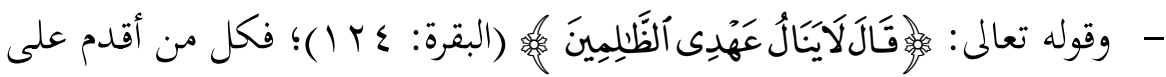

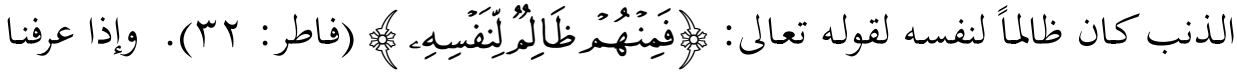

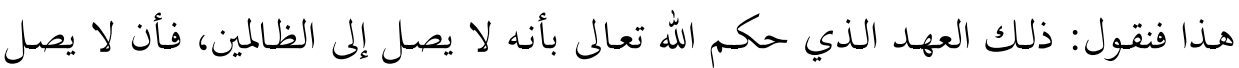

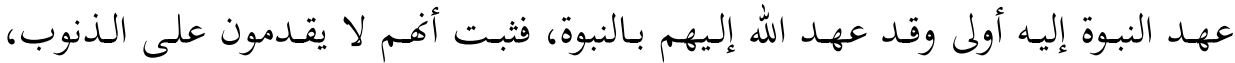

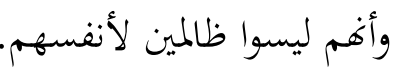

\section{r. بحث العصمة عند القاضي عياض (توفي ع هـه):}

اختار القاضي عياض نموذجاً عقده في كتابه "الشفا بشرح حقوق المصطفى"، وهو

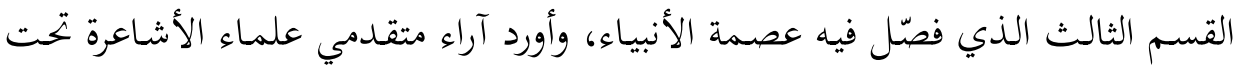

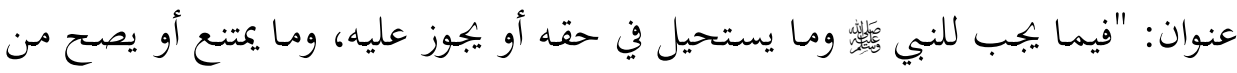

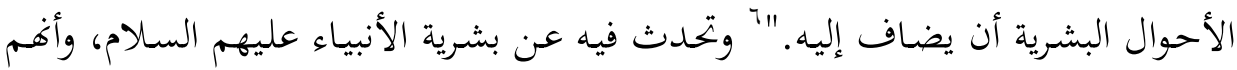

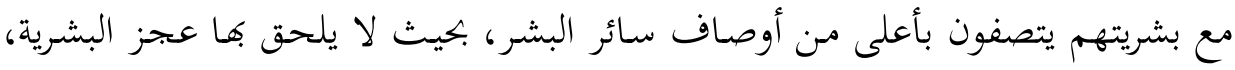
ولا ضعف الإنسانية. لومما جاء فيه: باعلى من أوصات

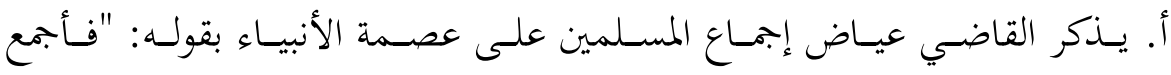

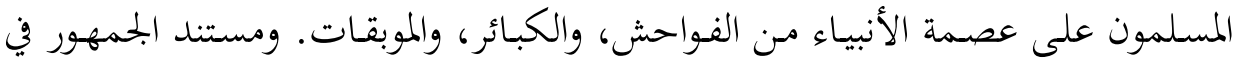

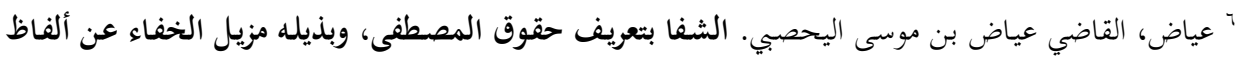

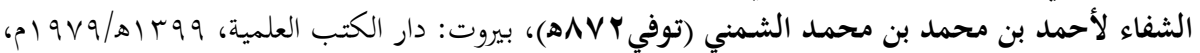


ذلك الإجماع... وهو قول كافتهم.... وكذلك لا خحلاف في أفهم معصومون من كتمان

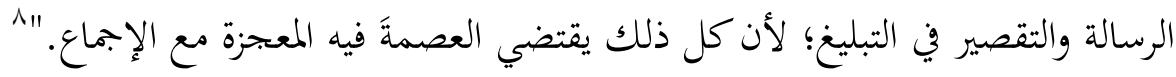
ب. وفي موضع آخر يقول: "لا أعلم أن الطوارئ بين المتغيرات والآفات على آحاد

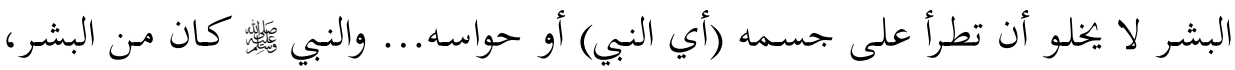

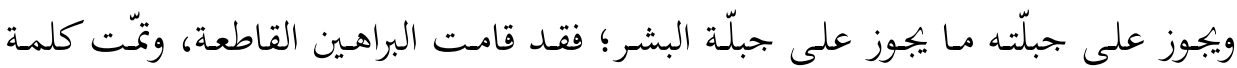
الإجماع على خروجهه عنهم، وتنزيهه عن كثير من الآفات التي تقع على الاختيار وغير الاختيار. الإنو

ت. عقد القاضي عياض فصلاً في حكم عقد قلب النبي

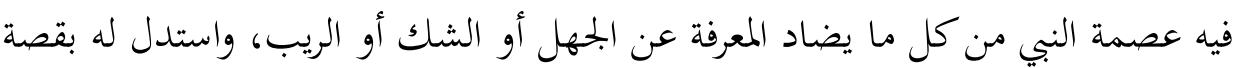

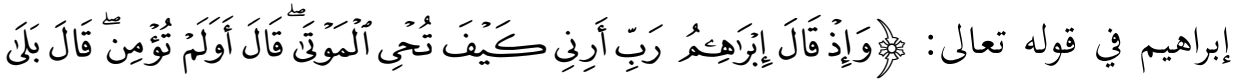

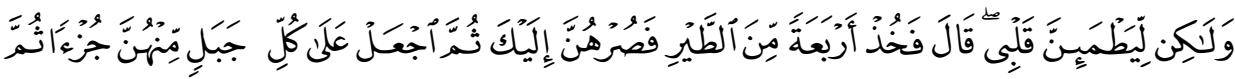

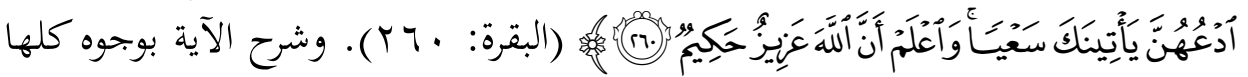
تدل على العصمة عن الشك.

ث. عقد فصلاً كذلك في عصمة الأنبياء قبل النبوة عن الكفر، والشك، والجهل بالله تعالى، مع الاستدلال العقلي على ذلك، وعدم وجود النقل على ما يخالفه، بل في النقل ما يؤيد عصمتهم عنه، وضرب لذلك أمثلة مما ورد في قصص النبيين في القرآن. 'ل ج. أنشأ فصالًا في إجماع الأمة على عصمة النبي من الشيطان، وحماية الله له منه،،

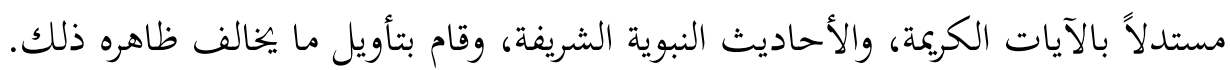
ح. عقـد فصـالًا في عصمة الأنبياء عـن الكذب في التبليغ، وأقام الأدلة الواضحة، وقدّم تفسيراً وتاويلاً، لما يُتوهم أنه يخالف العصمة في ذلك، وذلك بردّ الروايات الملفقة، بـاء

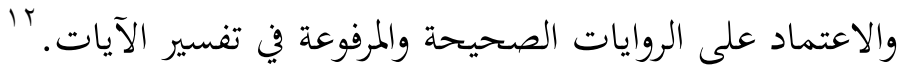

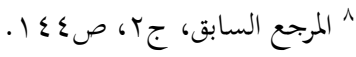

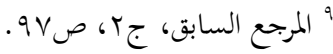

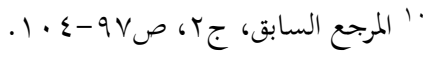

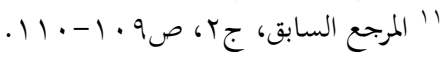




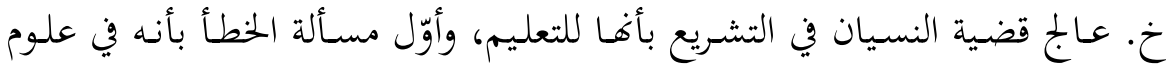

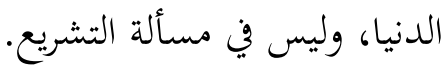
د. عالج قضية مـا عُرف بكذبات إبراهيم في حديث الشفاعة؛ وأن هذا ليس مـ

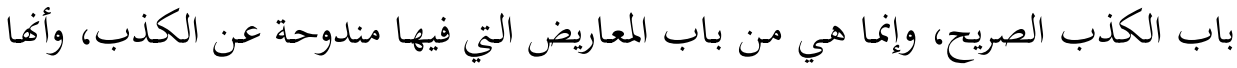

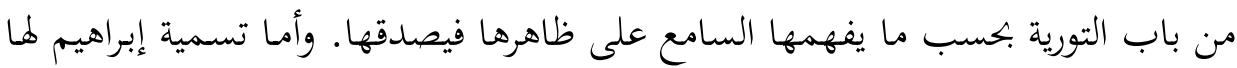

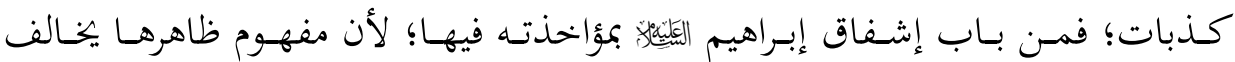

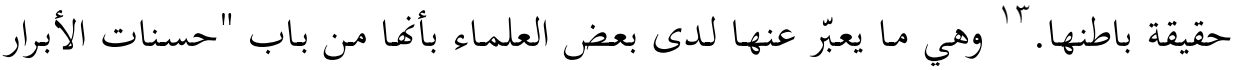

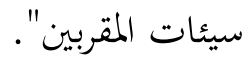
ذ. عقد فصلاً في مـا يتعلق بالأقوال والأفعال، وذكر إجماع المسلمين على عصمة

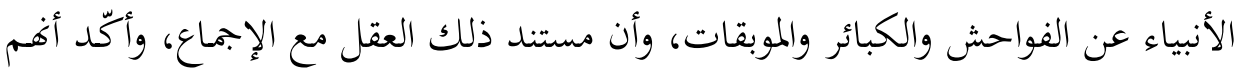

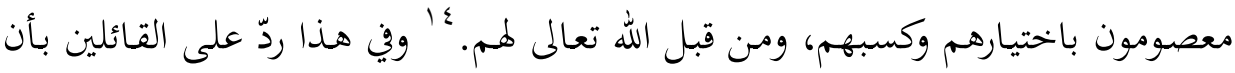
الله هو الذي صرفهم عن فعل المعصية بلا إرادة منهم ولا اختيار. وهكذا يؤكد القاضي عياض حقيقة العصمة بعد النبوة، وأفها قائمة على أمرين:

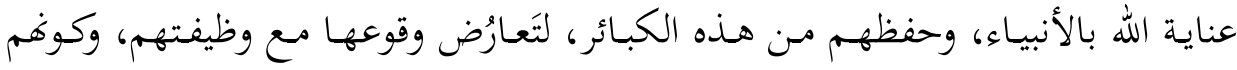

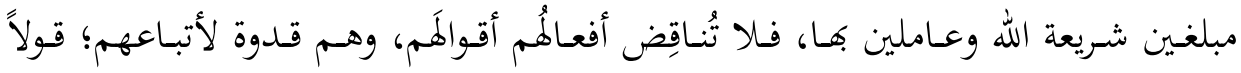

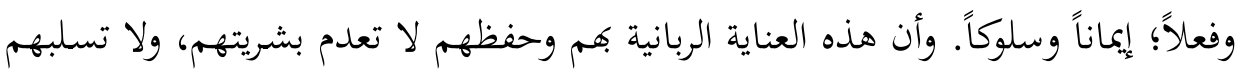

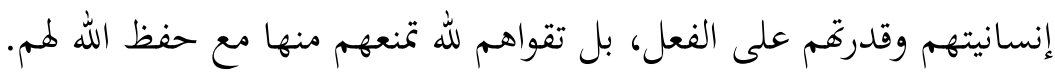

ر. ذكر القاضي عصمتهم من الصغائر بعد النبوة كعصمتهم من الكبائر؛ لاختلاف

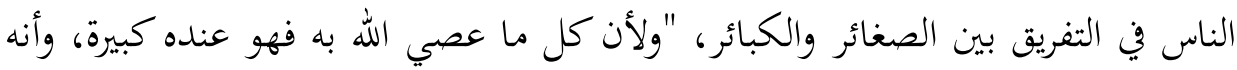

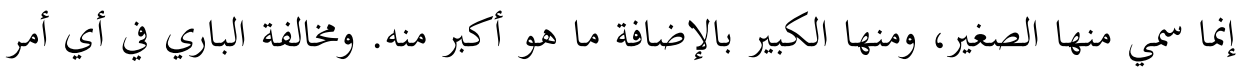

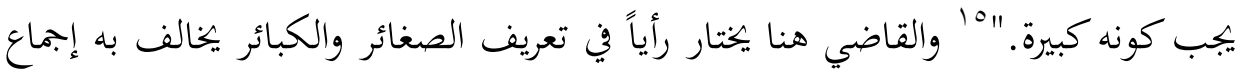

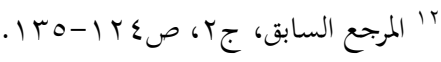

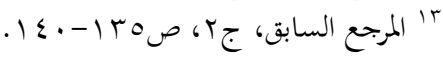

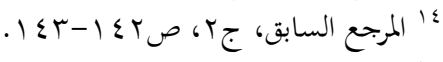

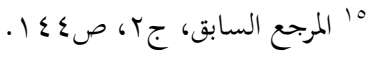


السلف الموافقين لنص الكتاب في تقسيم الذنوب إلى صغائر وكبائر بدليل قوله تعالى: مَ

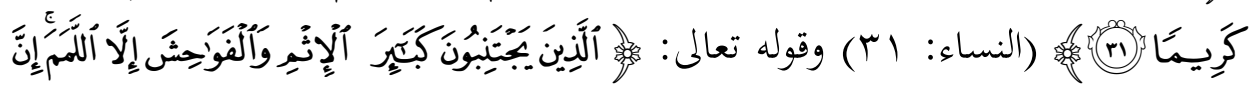

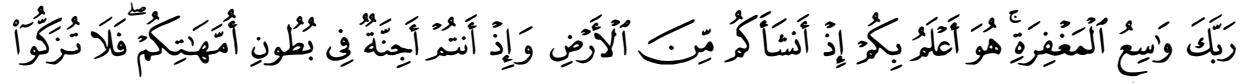

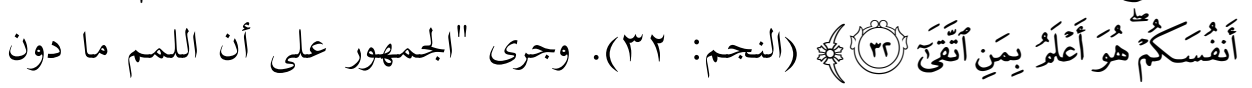

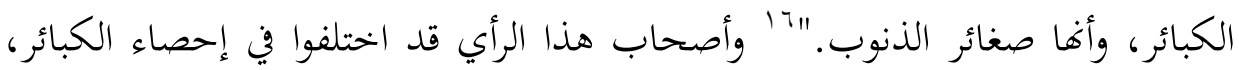
والتمييز بينها وبين الصغائر إلى أقوال متعددة؛ "منها أها الموبقات السبع، ومنها الشرك بالله، وعقوق الوالدين، وقتل النفس، واليمين الغموس ، ومنها أن كل ذنب ختمه الله بنار أو غضب أو لعنة او عذاب، أو ما توعد الله عليه حدّاً في الدنيا أو عذاباً في

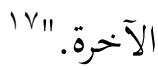

ز. عقــ القاضي عيـاض كـذلك فصـالا، ذكر فيـه الخـلاف في عصسمة الأنبيـاء عـن المعاصي قبل النبوة؛ إذ أجازها قوم ومنعها آخرون، ورجّح القاضي عدم عصمتهم عنها

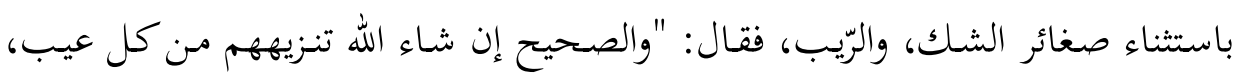
وعصدمتهم مـن كل مـا يوجـب الرَّيب، فكيف والمسألة تصورها كالممتنع، فيإن المعاصي والنواهي إنما تكون بعد تقرير الشرع."^|' وعزز هذا الرأي بقول من وصفه بسيف السنة،

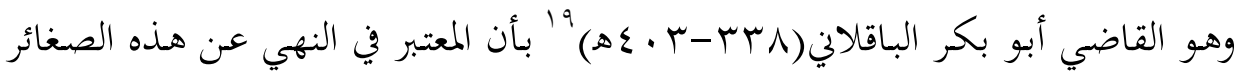
هو تقرير الشرع، أي طريق السمع، وهو غير حاصل قبل النبوة. س. وجاء بفصلٍ بعدم عصمة الأنبياء عمّا يكون من الأعمال بغير عمد كالسهو

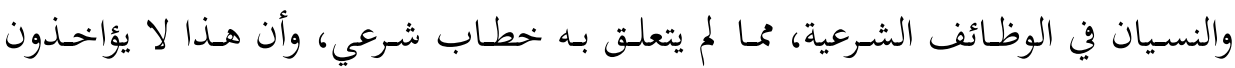

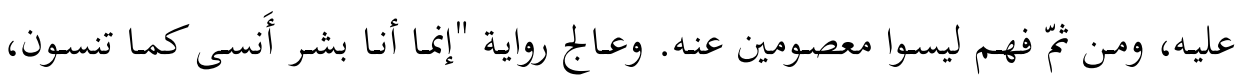

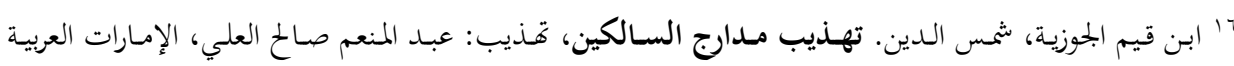

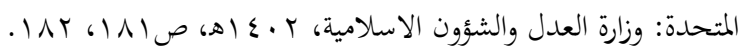

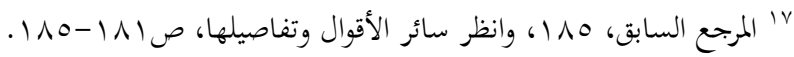

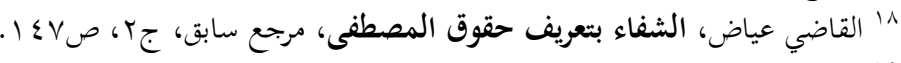

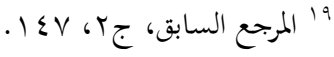


ro

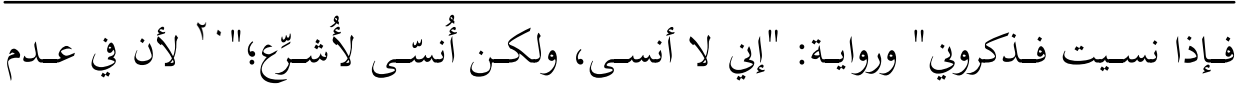
العصمة في هذه القضايا أن الأنبياء لا يقرون على السهو والغلط، بل لئ "ينبهون ويُعَرِفون

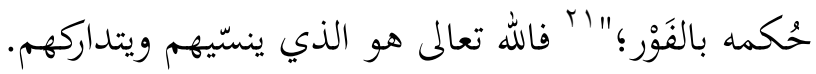

تم ذكر القاضي فصـالًاكـاملاً في الكـلام عن الأحاديـث النبويـة المذكور فيها سـهو النبي

ش. وهو فصل في الردّ على من أجاز الصغائر على الأنبياء من المتكلمـين والفقهاء،

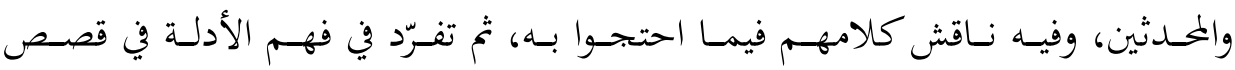
الأنبياء، بَّ وقدّم فهماً لها أصيلاً في مفهوم العصمة بعيداً عن ضغوط فئم الروايات الإسرائيلية في فهم الآيات، بل لم يناقش واحدة منها، ولا أتى برواية من رواياها كما فعل المفسرون.

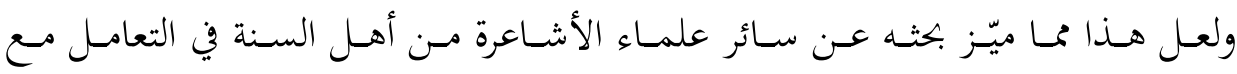
الإسرائيليات الواردة في كتب التفسير، وقصص الأنبياء، ومن ثمّ يمكن تلخيص العصمة عنـد القاضي عيـاض فيمـا عقـده فصـاً ختاميـاً في عصـمة الأنبيـاء، وكأنه نتيجـة لعمليـة تحليلية لنصوص القرآن، بعيدة عن الجحل؛ إذ بدأ فصله ذاك بقوله: "قد استبان لك أيها

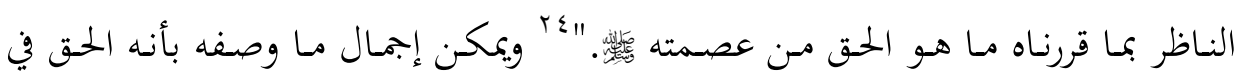

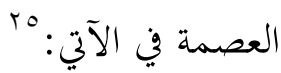

- النبي معصوم عن الكفر، والجهل بالله وصفاته مطلقاً قبل البعثة وبعدها. - النبي معصوم عن الكذب قبل النبوة وبعدها مطلقاً.

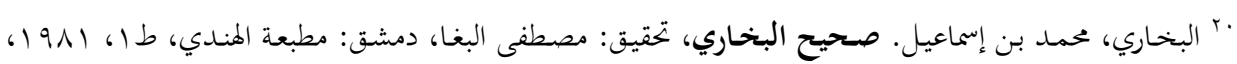

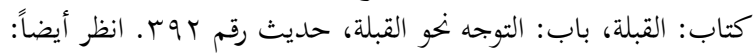

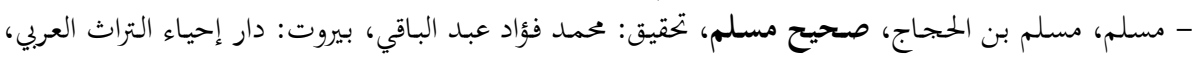

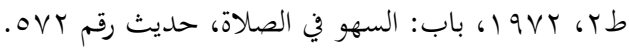

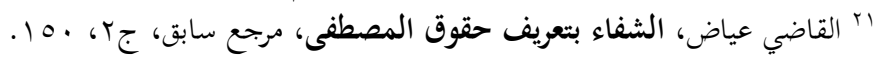
rr

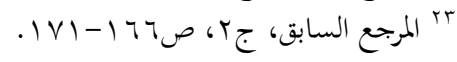
م • 
- النبي معصسوم عن الكبائر إجماعـاً، وعن الصغائر تحقيقـاً، وعن استدامة السهو

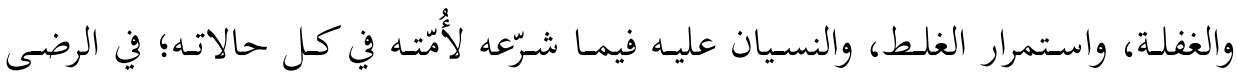
والغضب، وفي الجمد والمزاح.

\section{ع. قواعد العصمة عند كبار علماء الأشاعرة:}

وضع هؤلاء العلماء قواعد متقاربة تحكم قضية العصمة، وتفهم الآيات في ضوئها، وأوّلوا قصص القرآن وروايات أهل الكتاب في ضوئها. ولنعرض هذه القواعد عن بعض كبار أئمة هذه المدرسة:

أ. قواعد العصمة عند الجويني (توفي \& \&ه):

يذكر الجويني قواعد العصمة عنده على النحو الآتي:

القاعدة الأولى: بجـب عصمتهم عما يناقض مدلول المعجزة، وهذا مما نعلمه عقلاً، ومدلول المعجزة صدقهم فيما يبلغون.

القاعدة الثانية: أمـا الفواحش المؤْذِنة بالسقوط وقلة الديانة، فتجب عصمة الأنبياء عنها إجمالاً.

القاعدة الثالثة: وأما الذنوب المعدودة مس الصغائر على تفصيل فلا تنفيها العقول، ولم يقـم عندي دليل شخصي على نفيها، ولا على إثباتها؛ إذ العلماء مختلفون في بتحويز

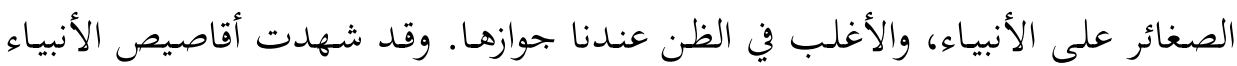
من كتاب الله على ذلك.

\section{ب. قواعد العصمة عن الإمام الرازي (توفي ج • 7ه):}

وقــ أجمـل الرازي قواعـد العصـمة عنـــ أهـل السـنة -وذذكر بحمـل آراء غـيرهم مـن

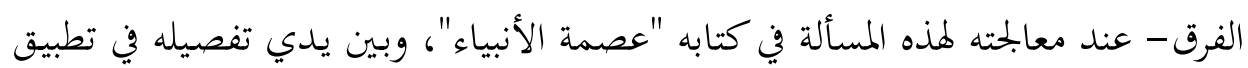

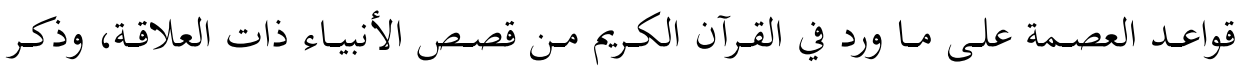
بr الجويني، عبد الملك بن عبد الله. الإرشاد إلى قواطع الأدلة في أصول الاعتقاد، تحقيق: أسعد تميم، بيروت:

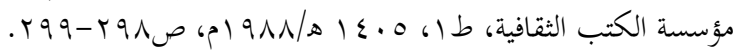




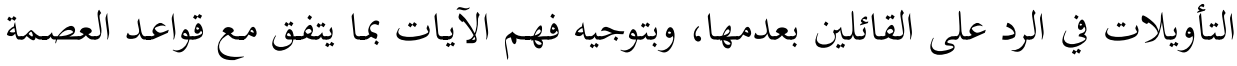

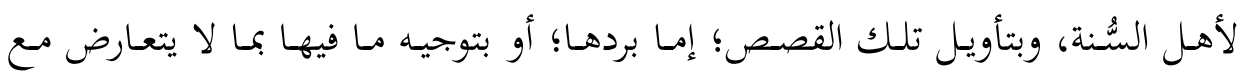

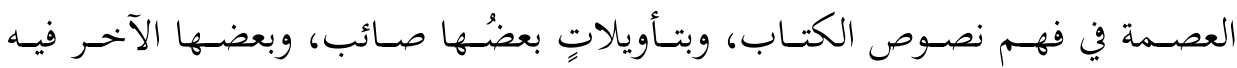

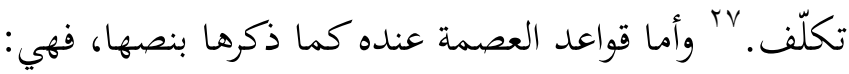
القاعدة الأولى: ما يتعلق بالاعتقادية، فقد أجمعت الأمة على أن الأنبياء معصومون

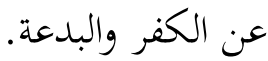
القاعدة الثانية: ما يتعلق بجميع الشرائع والأحكام من الله تعالى، فقد أجمعوا على أنه

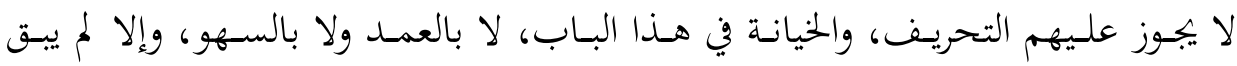
الاعتماد على شيء من الشرائع. القاعدة الثالثة: ما يتعلق بالفتوى، أجمعوا على أنه لا يجوز تعمّد الخطأ، وأما إن كان على سبيل السهو فقد اختلفوا فيه. القاعدة الرابعة: مـا يتعلق بأفعالهم وأحوالهم....، والذي نقول: "إن الأنبياء عليهم الصلاة والسلام معصومون في زمان النبوة عن الكبائر والصغائر بالعمد. أما على سبيل

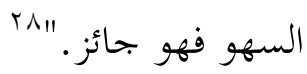

\section{ت. قواعد العصمة لدى ابن خُمَير السّبتي(توفيع الهه):}

جاءت هذه القواعد في كتابه "تنزيه الأنبياء عمّا نسب إليهم حثالة الأغبياء"؛ إذ

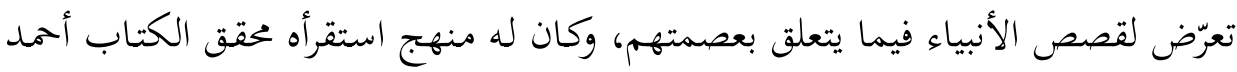

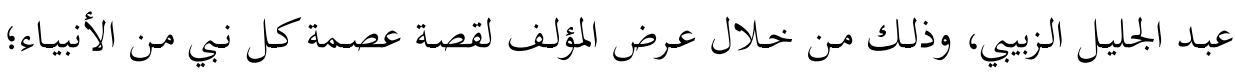

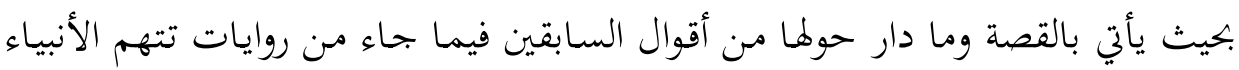

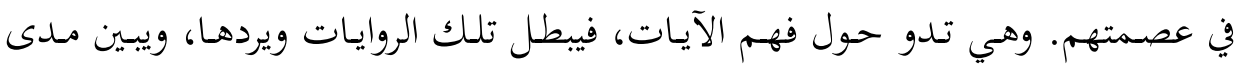

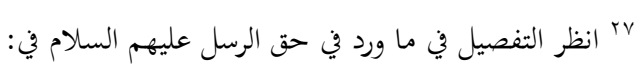

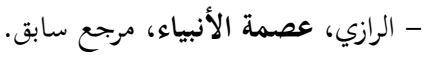

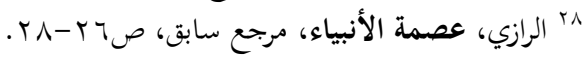


خطورتا على العصمة، ويعالج الآيات بمنطق سليم بعيد عن الإسرائيليات، ويعتمد -إن وجدا- على ما صح من الروايات. ويمكن تلخيص قواعد منهجه جَr بما يأيت:

القاعـدة الأولى: واضـح مـن اسم الكتـاب أنه بحـث في تنزيه الأنبياء عمّا تورط فيـه القصـاص والأغبيـاء -في نظر ابـن خمير- في روايـاتم لقصص وردت في كتـب التفسير تطعن بعصمة الأنبياء، وكانت أساساً لموضوع العصمة في كتب التوحيد، وأنه لا يصح الاعتماد عليها.

القاعـدة الثانيـة: يـرى ضـرورة الاعتمـاد على الأخبـار الصـحيحة فقـط في قصصص الأنبياء.

القاعـدة الثالثة: إجمـاع الأمـة على عصمة الأنبياء مـن الكبائر، وعلى اختـلافهم في

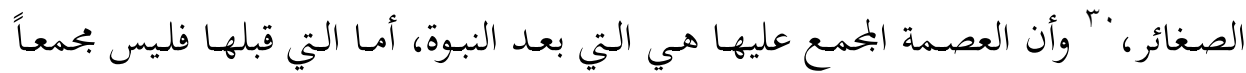

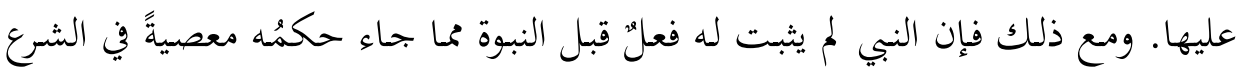

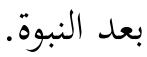

القاعدة الرابعة: كل مخظور عنده كبيرّ، وكأنه لا يفرّق بين الصغائر والكبائر على

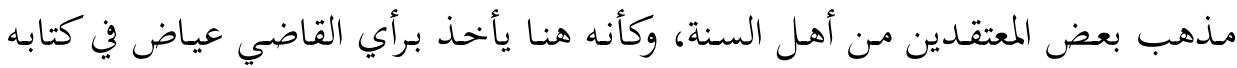

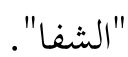

القاعدة الخامسة: غاية ما وقع من الأنبياء في قصصهم في القرآن-في رأيه- هو من

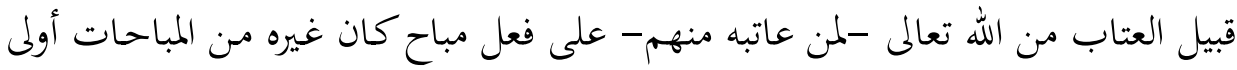

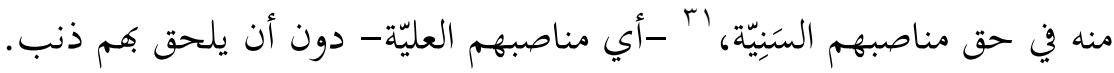
القاعدة السادسة: ما وقع منهم مـن بعض المباحات مما عددت ذنوباً هي من باب

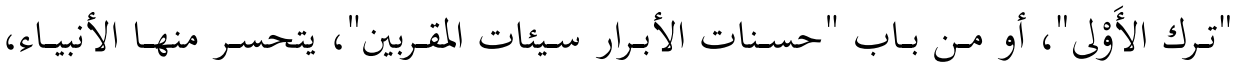

ويندمون عليها ويستغفرون منها.

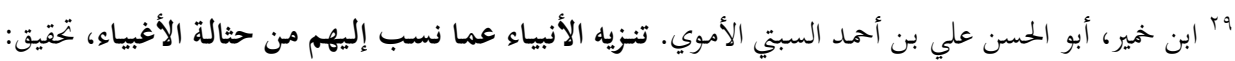

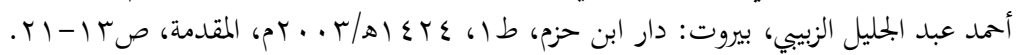

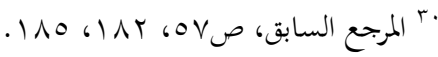

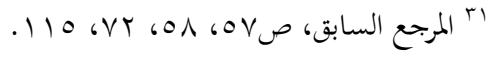


القاعـدة السـابعة: يرى أنه لولا مـا وقع مـن الخـلاف في هـذه القضية مـن الجهال المتعصبين، ومن الروايات التي تقدح في تنزيه الأنبياء؛ لكان ترك البحث في هذه احثه الآيات أولى. وهذه منهجية متميزة لدى ابن خمير.

\section{ث. قواعد العصمة عند الآمدي (توفي اسبهد):}

بندـ الآمدي في كتابه "أبكار الأفكار" يعالج عصمة الأنبياء، وقد فصّل في بيـان قواعدها عند علماء الأشاعرة، قبل النبوة وبعدها، على النحو الآتي:

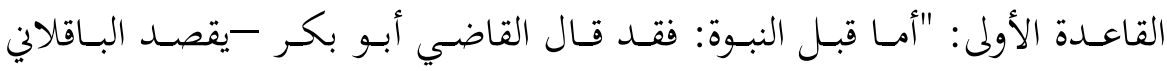

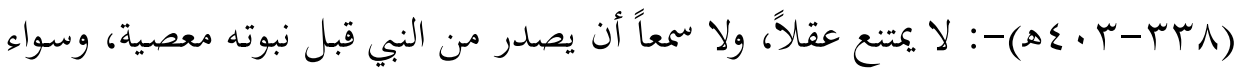

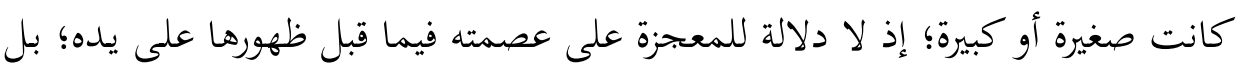

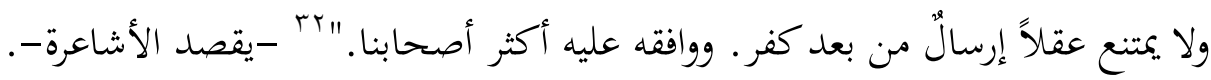

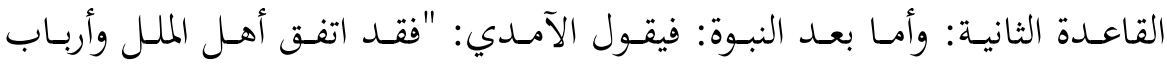
الشرائع على وجوب عصمة الأنبياء -عليهم السلام - عن الكذذب عمداً فيمـا دلّت

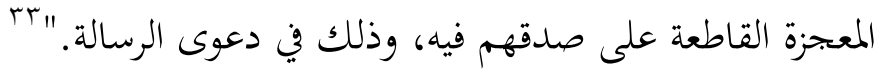

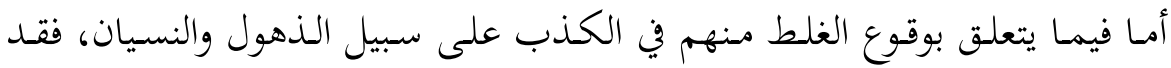

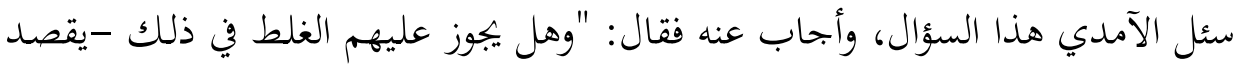

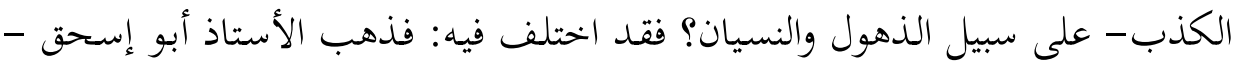

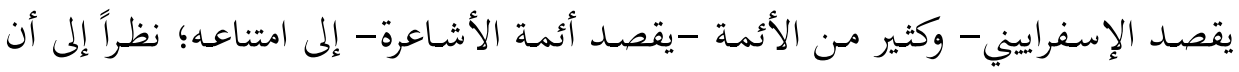

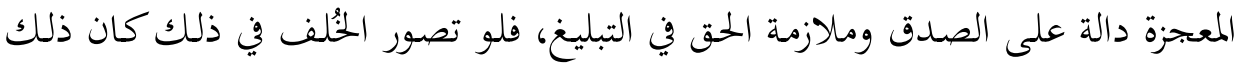

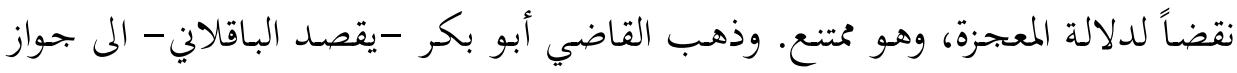

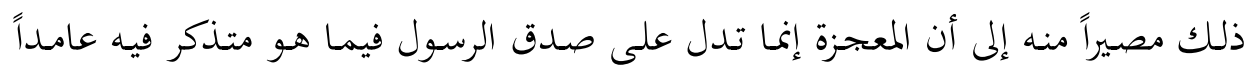

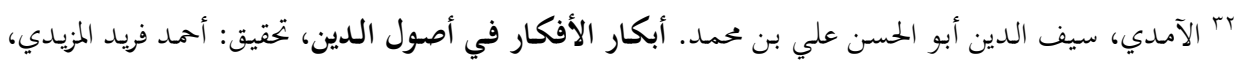

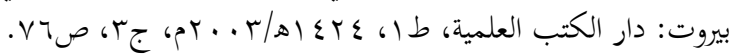

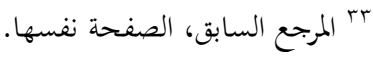


له. وأما ما كان من النسيان وفلتات اللسان فلا يدخل تحت التصديق المقصود بالمعجزة،

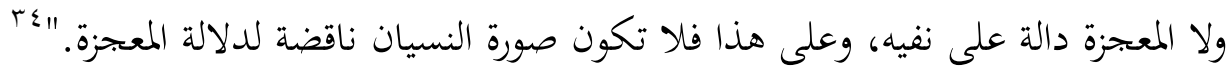
القاعـدة الثالثـة: ثم استـكمل الآمـدي عصسمة الأنبيـاء في الأفعـال والأقوال، فقـال: "وأما ما يتعلق بأفعالهم وأقوالهم، فلا دلالة للمعجزة على صدقهم فيه؛ فإما أن يكون كفراً

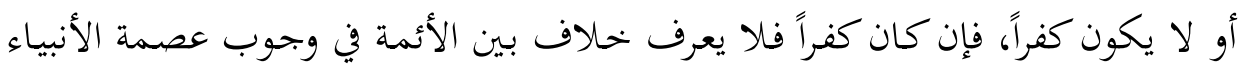

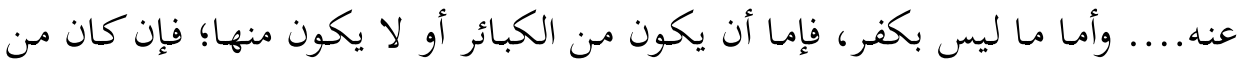

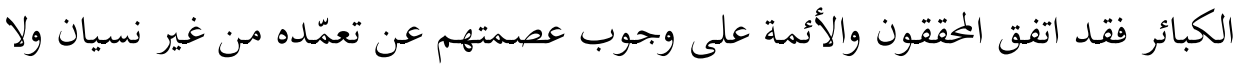

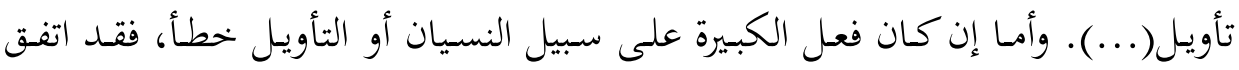

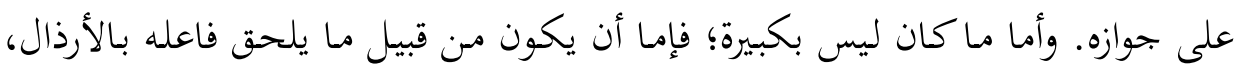

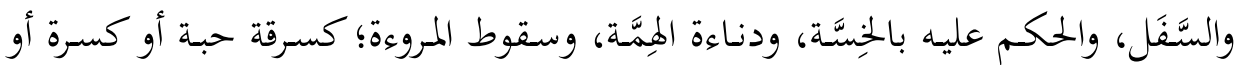
نحوه، فالحلكم فيه حكم الكبيرة، -ويقصد وجوب عصمتهم عن تعمده من غير نسيان

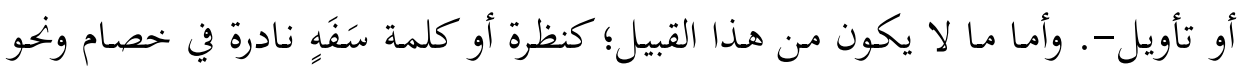

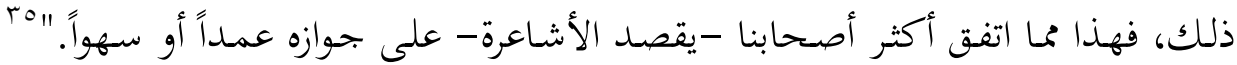

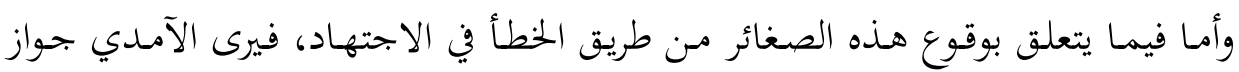

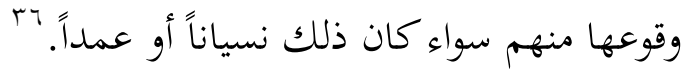

ثم أخــ الآمـــي يطبـق هـذه القاعـدة في العصـمة على بعض الأحسداث في حيـاة

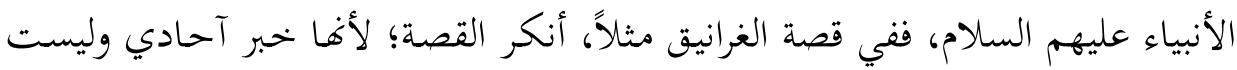

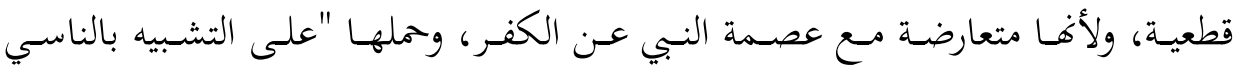

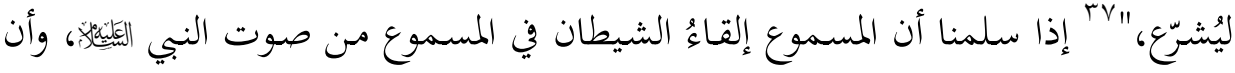

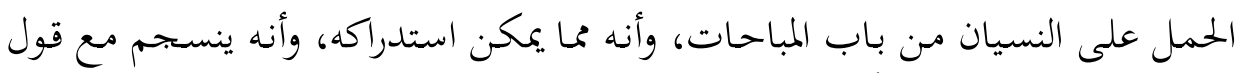

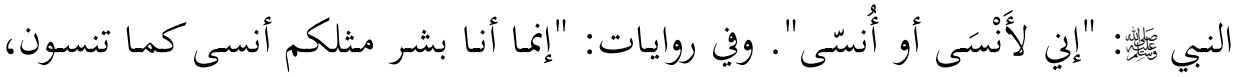

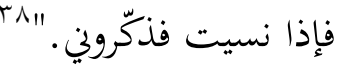

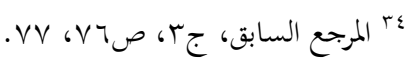

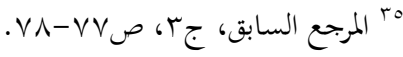

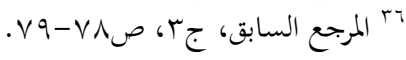

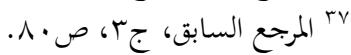

^^r البخاري، صحيح البخاري، مرجع سابق، كتاب: القبلة، باب: التوجه نحو القبلة، حديث رقم جهr. انظر أيضاً: 


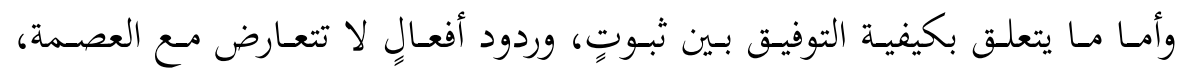

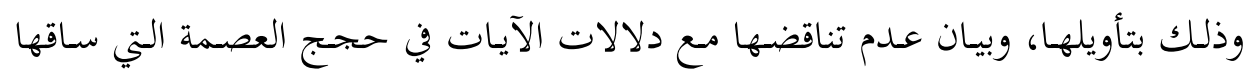

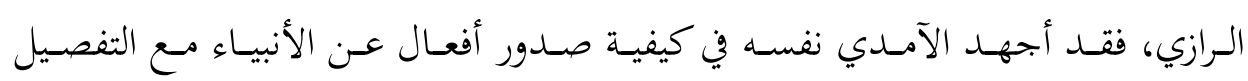

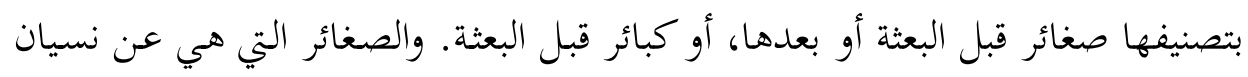

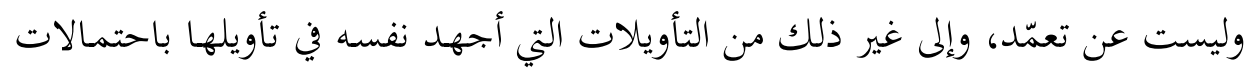

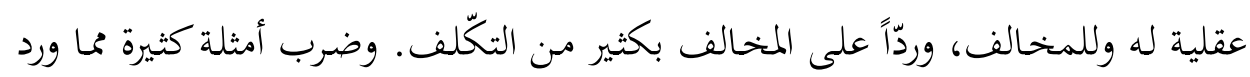
في قصص الأنبياء.

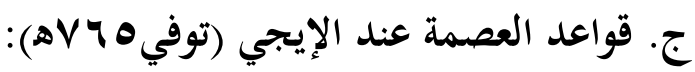

جمع الإيجي قواعد العصمة عند الأشاعرة من أهل السّنة بوصفه موسوعياً متأخراً، وذلك في كتابه "المواقف"، في النقاط الآتية:

القاعدة الأولى: أجمع أهل الملل والشرائع على عصمة الأنبياء عن تعمّد الكذب فيما

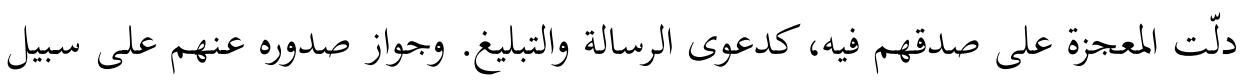

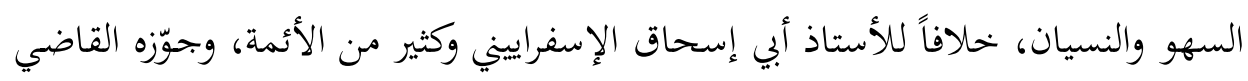
الباقلالن.

القاعدة الثانية: أجمعت الأمّة على عصمتهم عن الكفر مطلقاً قبل النبوة وبعدها، عمداً أو سهواً.

القاعدة الثالثة: الأنبياء معصومون عن الكبائر بعد النبوة مطلقاً، أي عمداً وسهواً.

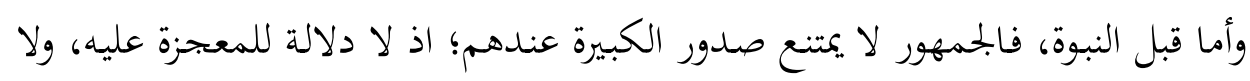
حكم للعقل عليه أيضاً.

القاعـدة الرابعـة: الأنبيـاء غير معصـومين عـن الصغائر قبـل النبوة مـن غـير صغائر الحِيسَّة، وهم معصومون عن صغائر الخسة؛ لأهما منفّرة.

- مسلم، صحيح مسلم، كتاب المساجد، باب: السهو في الصلاة، حديث رقمبهو.

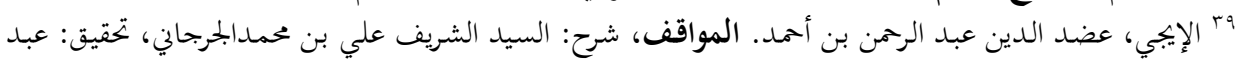

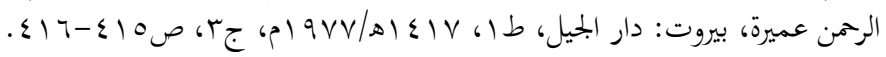


القاعدة الخامسة: الأنبياء معصومون عن الصغائر بعد النبوة عمداً، وغير معصومين عنها سهواً، ونسياناً أو خطأ في التأويل.

وملخص تلكك القواعـد عند الأشـاعرة قولهم في العصـمة: الأنبياء معصسومون زمان نبوهم عن الكبائر مطلقاً، وعن الصغائر عمداً. وقـد جـاء الإيجي بكـل مـا جـاء بـه مـن قبله مـن أدلّة العصـمة الشـرعية، وتطبيق

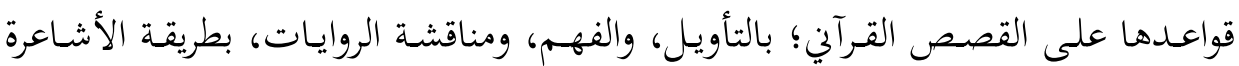
نفسها.

ثانياً: العصمة في قصص الأنبياء في القرآن الكريم

\section{I ـ عناية القرآن بالأنبياء في قصصه:}

عرض القرآن الكريم قضية النبوة ركناً من أركان الإيمان، وعرض الأهـداف من بعثة

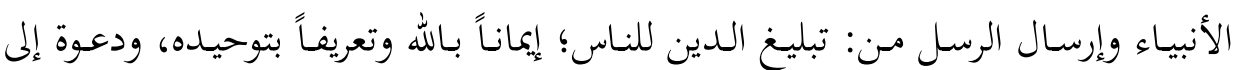
عبادته وحده لا شريك له.

كما هدف الى بيان شريعته، وإقامة العدل، ودعا إلى محاسن الأفعال، ومكارم

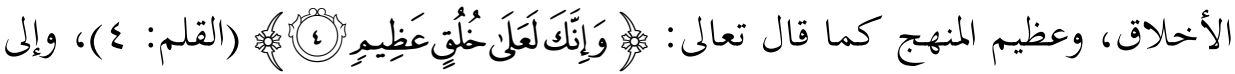
بيان المعاد وما ينتظر الناس في الآخرة من جزاء، فالأنبياء حجة الله على خلقه كما قال

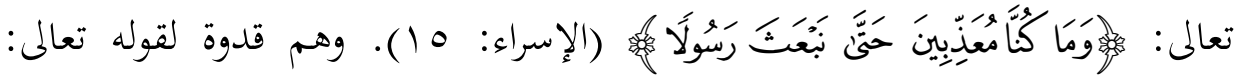

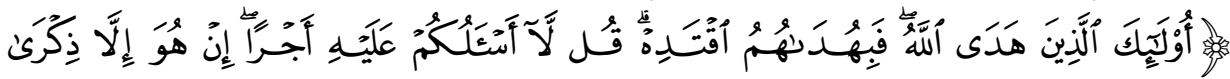

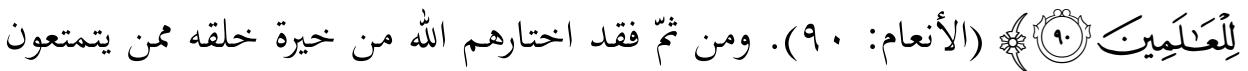
بفطرة سليمة، ولم يعرف عنهم عيب، وليس فيهم ما يُنبّر الناس منهم. وقد ظهر أثر عناية الله بهم قبل نبوقم كما هو معروف من سيرهم عند أقوامهم،

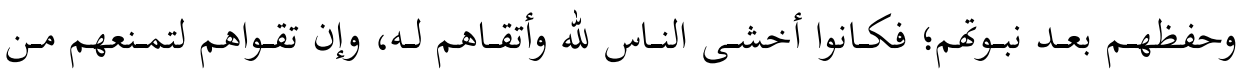
الوقوع في ما يتعارض مع وظائفهم ومواقفهم في التأسي والاقتداء. 


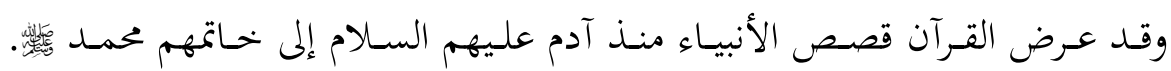

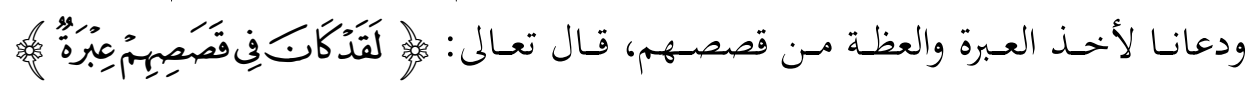

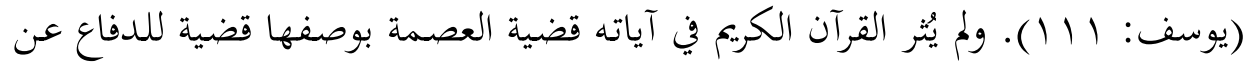

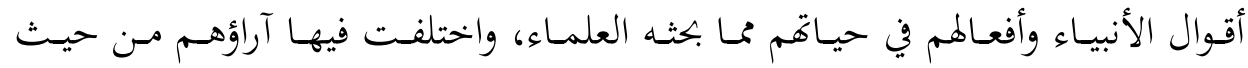

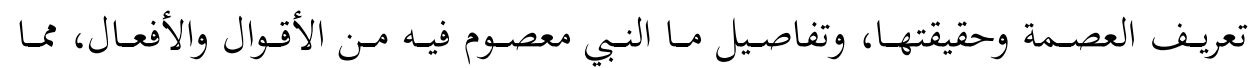

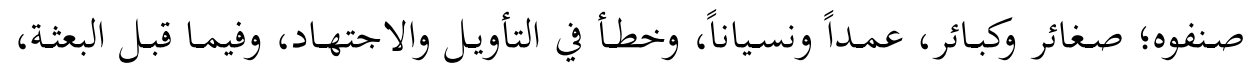

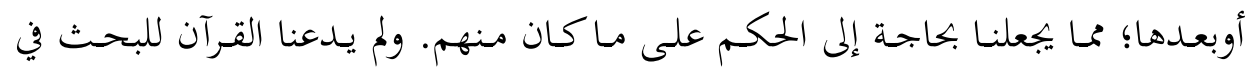

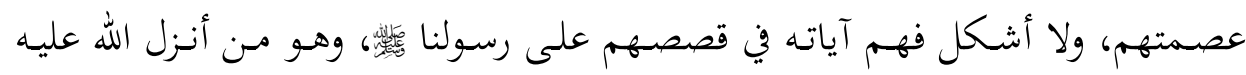

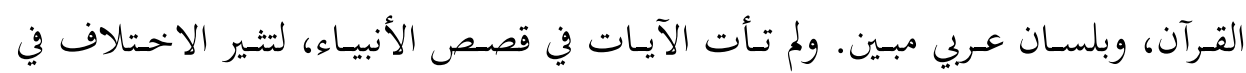

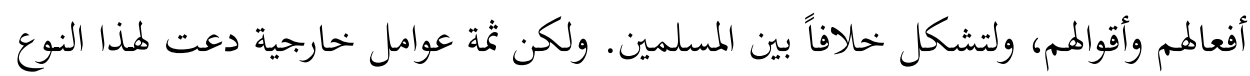

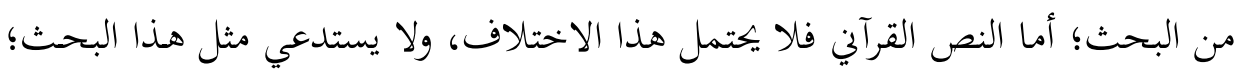

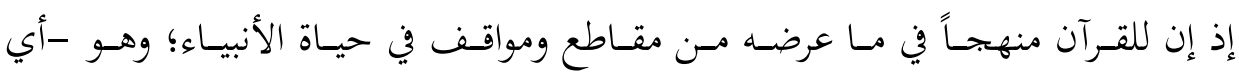

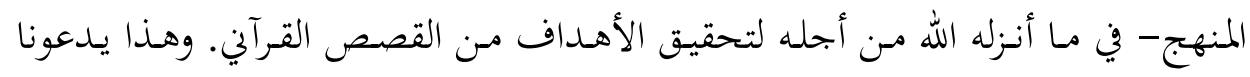

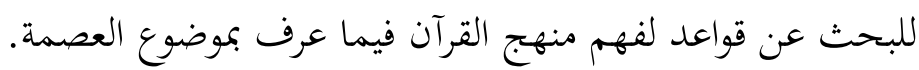

\section{r. قواعد لفهم العصمة في القرآن الكريم:}

بدراستنا لقصص القرآن الكريع، يمكننا استنباط القواعد الآتية التي على ضوئها يمكن

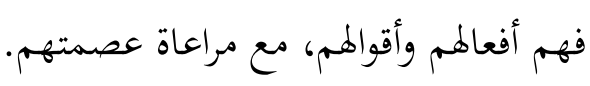

القاعـدة الأولى: الأهـداف العامـة لآيـات بحثت بـأن لها علاقة بالعصـمة في القرآن

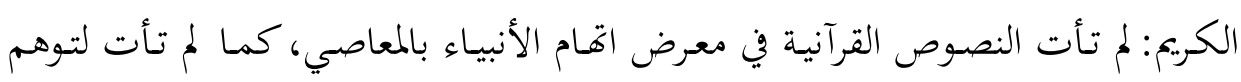

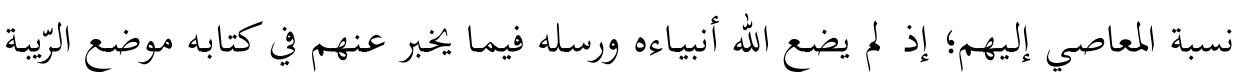

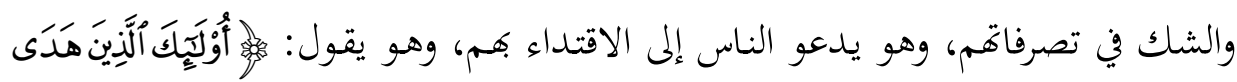

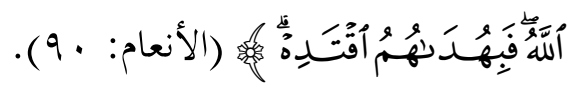

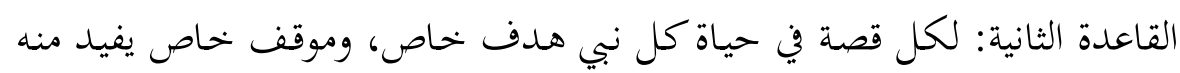

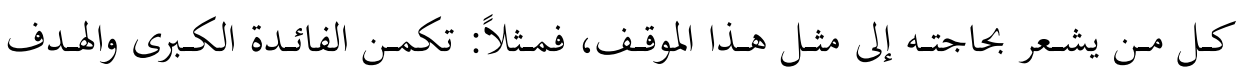


الأسمى للشاب المتعفف، المستعصـم بالله، وبأخلاق الإسلام حين يقع في فتنة المرأة، في

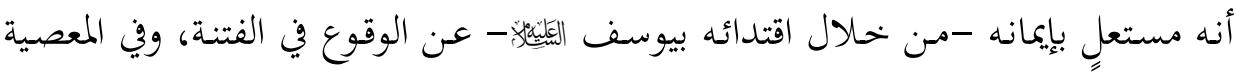

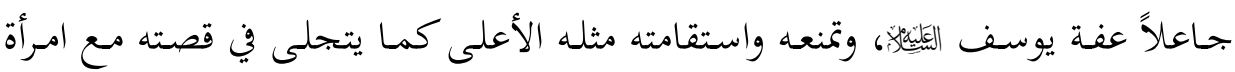

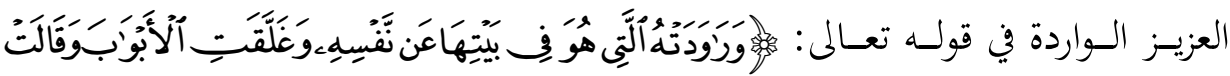

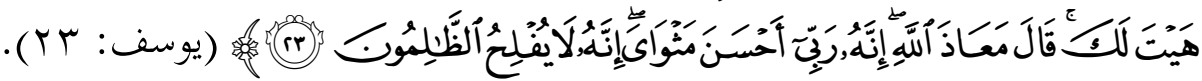
وفي باب جدال أهل الباطل، والاستدلال بالحقائق، يجعل الله المثل الأعلى في ذلك منهج الجدال بالتي هي أحسن كما في قصة إبراهيم مع قومه في الاستدلال على فساد

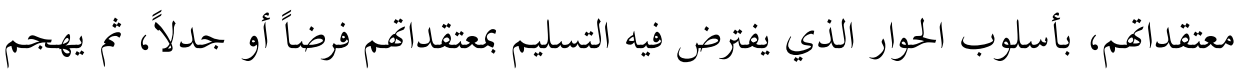
عليها ببيان فسادها عقلاً، لينتهي بهم إلى الدعوة إلى الإيمان بالله تعالى، ودعوقمم إلى

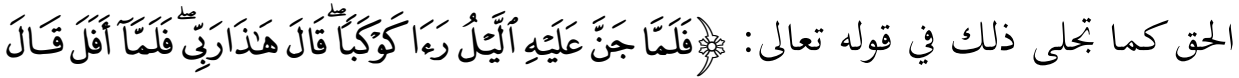

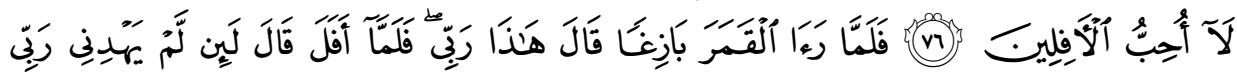

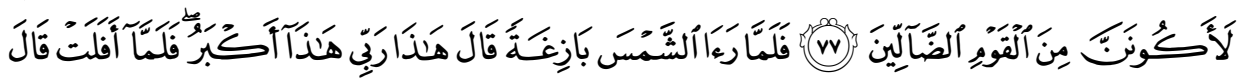

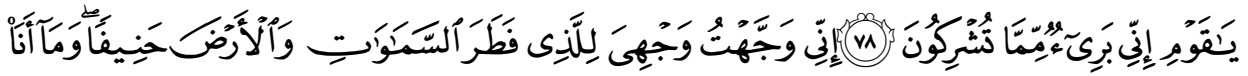

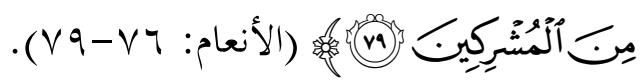

ويتعلم المؤمن المثل الأعلى في الصبر على المصائب من المرض، وفَقْد الولد والأهل

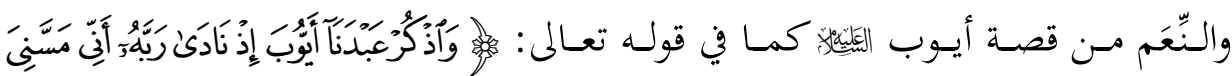

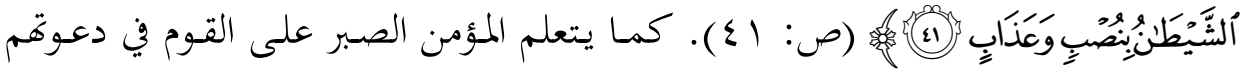

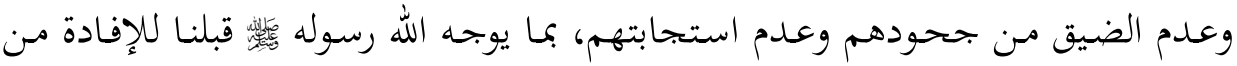

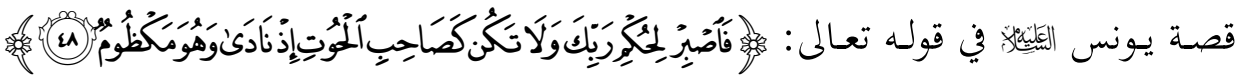

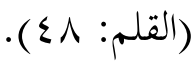

ويتعلم المؤمن طريق العودة المى الله، والإنابة إليه من قصة آدم اليلّنَّ)؛ إذ يعرف فيها

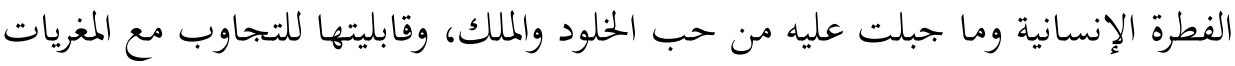
والشهوات، ليصون نفسه، وكيف له أن يصون نفسه، ويمذر من وساوس الشيطان،

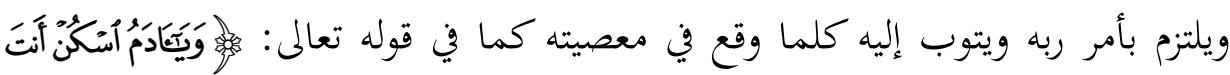




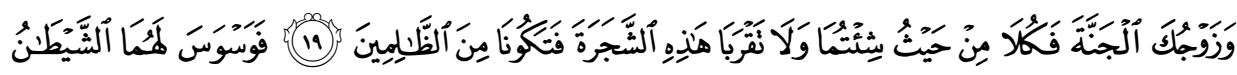

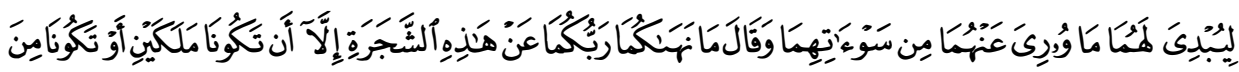

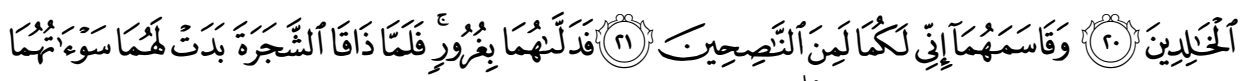

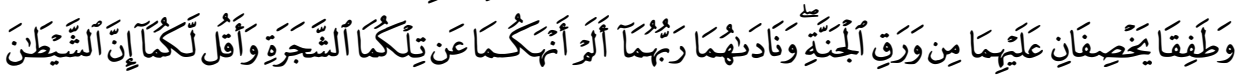

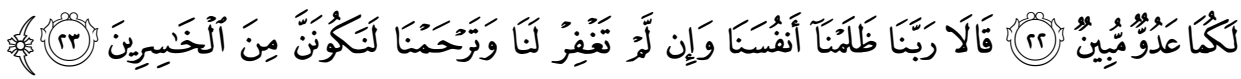

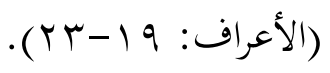

ويتعلم المؤمن معنى تقديم العلاقة الإيمانية على سائر الروابط، من قصة نوح الئلئهل

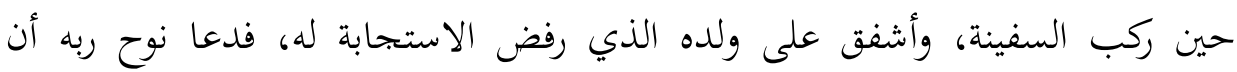

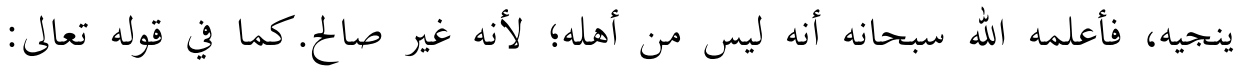

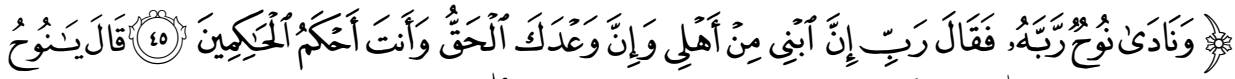

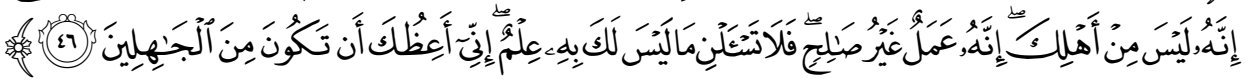

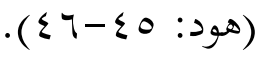

ويتعلم المؤمن أصول الحكم والقضاء العادل بين الناس الذي من أصوله أن يسمع القاضي من الطرفين المتخاصمين، ليقضي بينهما، وأن لا يكتفي بسماع طرف واحد

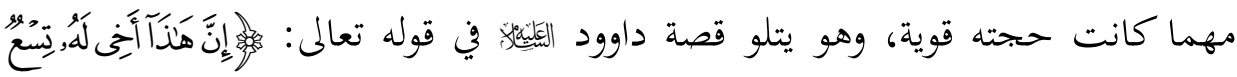

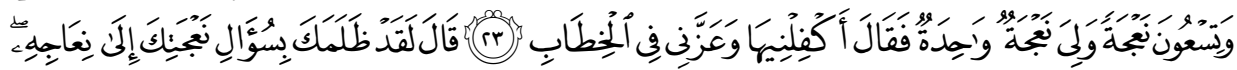

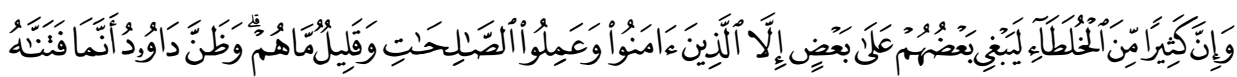

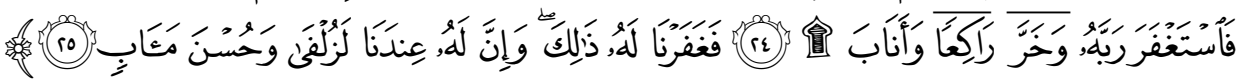
(ص:rr-ro-r). ونلاحظ أن هذه الآيات وغيرها من قصص القرآن، لا تثير من قريب أو بعيد دفاعاً عن مواقف تقع في باب المعاصي حتى تبحث فيما يوهم عدم العصمة. القاعدة الثالثة: إدراك البعد البشري في طبيعة الأنبياء، والأبعاد الواقعية لتصرفاهم؛

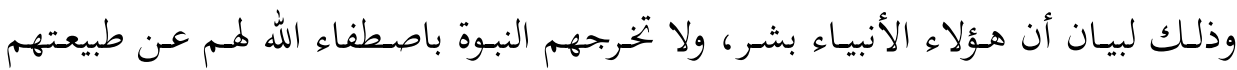

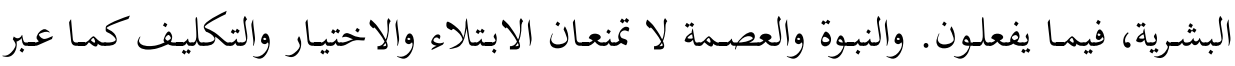

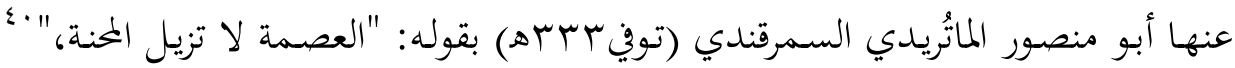
• ألماتريدي، أبو منصور محمد بن محمد بن محمود السمرقندي. تأويلات أهل السنة، تحقيق: محمد مستفيض الرحمن،

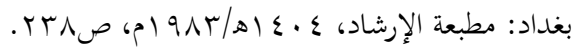


بمعنى أها لا تجبره على الطاعة، ولا تعجزه عن المعصية؛ '؛ فإن ما يتعرضون له من مواقف

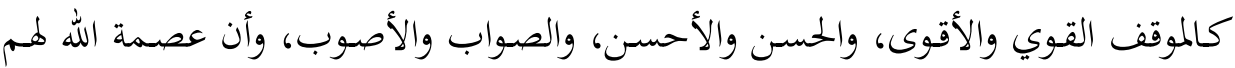

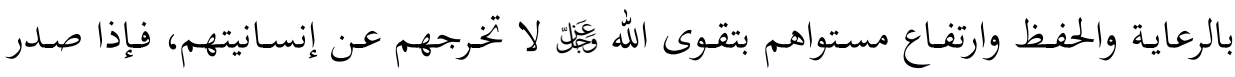

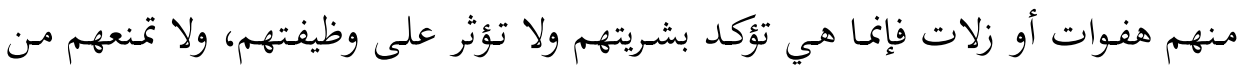

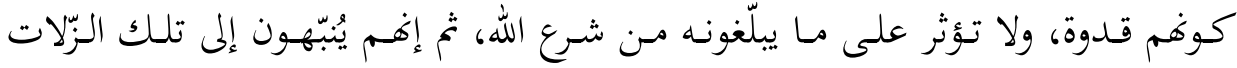

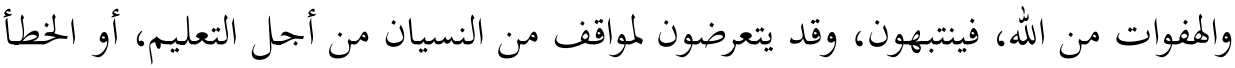

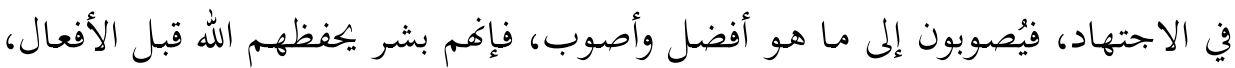
وبعد الأفعال؛ لأداء وظائفهم السامية.

وأمـاكـوفم يهاسـبون أنفسـهم على مـا صـدر مـنهم، فيستغفرون وينسبون الظلـم

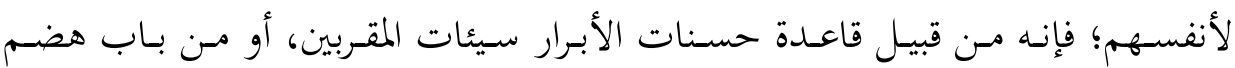

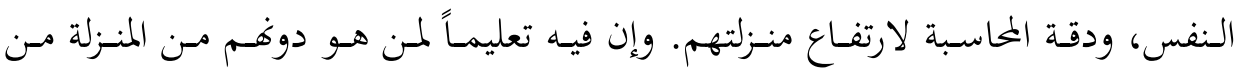

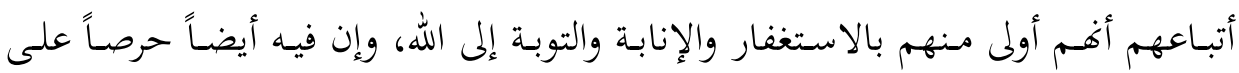

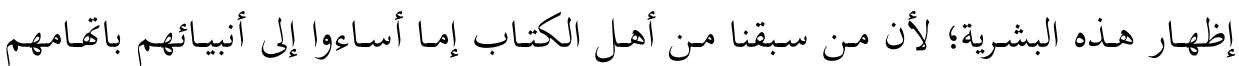

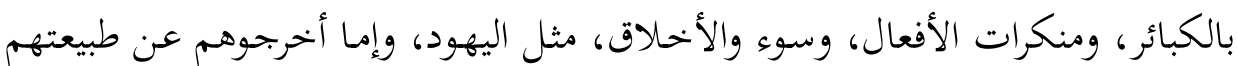

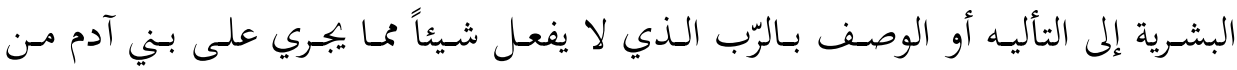
الهفوات، كما فعل النصارى مع عيسى اليَلِيَّهُ. القاعدة الرابعة: ضرورة فهم أحداث القصة في سياقاها؛ إذ لا بدّ أيضاً من أن نفهم

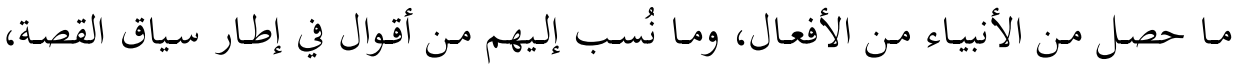

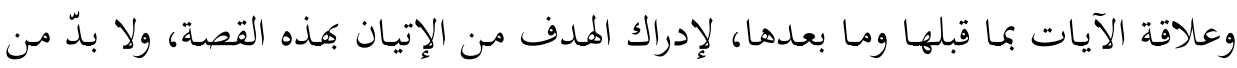

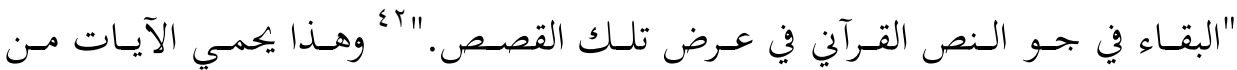

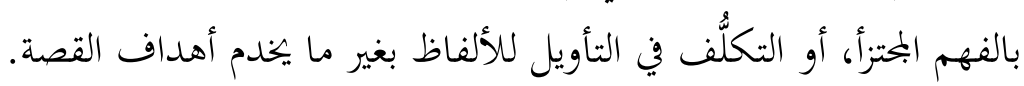

القاعدة الخامسة: اتفاق لغة النص فهماً وتأويلاً مع معهود العرب في الخطاب؛ فلا تفهم الألفاظ بغير ما جاء في لغة العرب وبأساليبهم، فبإن الله تعالى أنزل القرآن بلسان اء الصابوني، نور الدين أحمد بن محمود. كتاب البداية من الكفاية في الهداية في أصول الدين، تحقيق: فتح الله

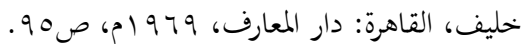

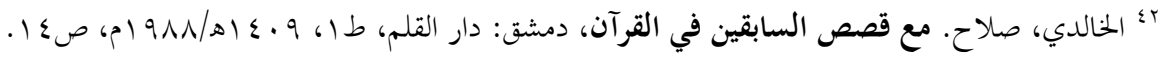


عربي مبين. وبهذا نستطيع أن نبتعد عن قصص بني إسرائيل في فهم آيات الكتاب العزيز؛

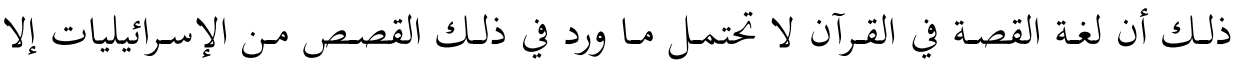

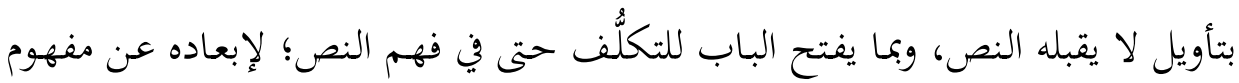

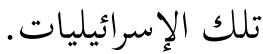

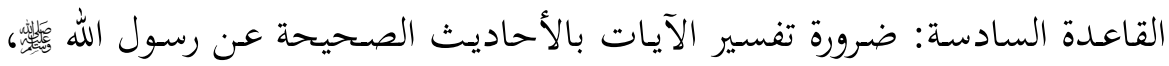

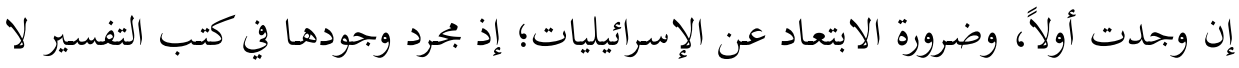

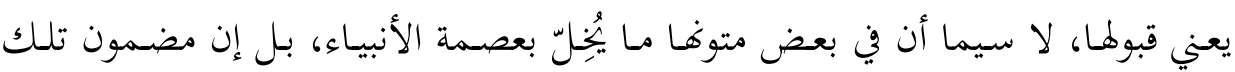

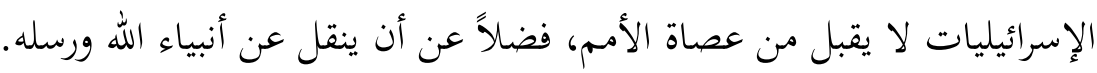

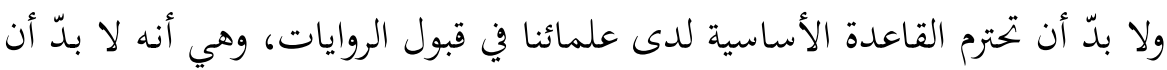

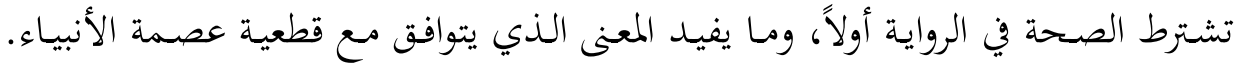

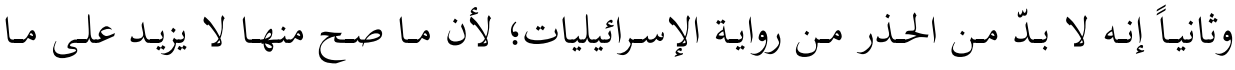

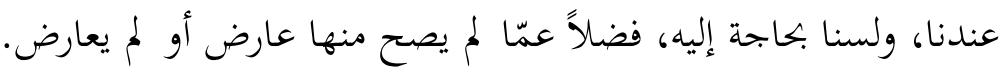

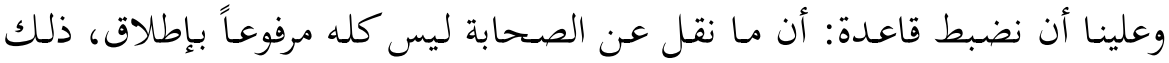

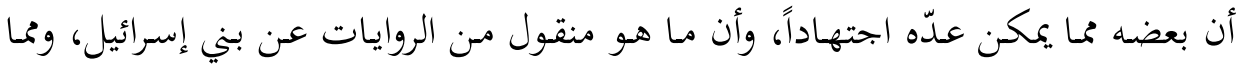

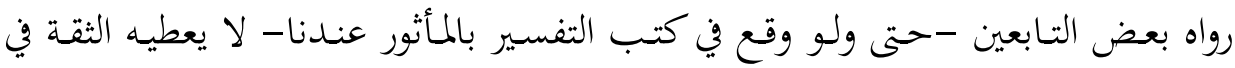

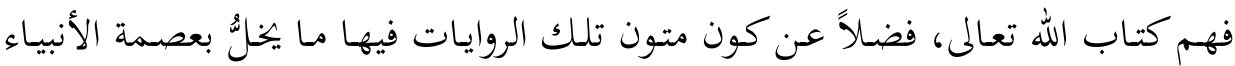

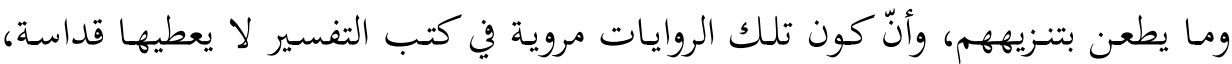

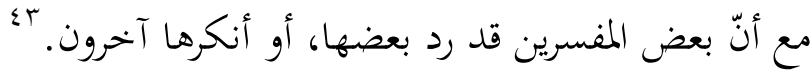

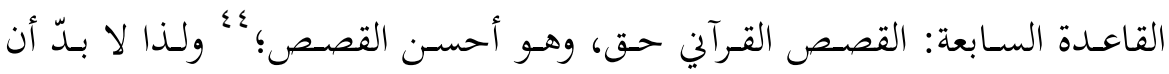

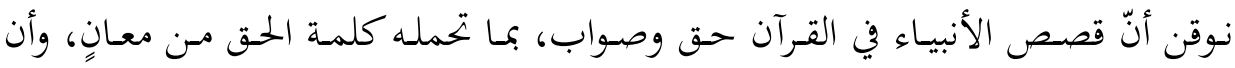

rا؛ راجع في هـا تفسير الطبري. وتفسير ابن كثير فيما ينبه فيه على الإسرائيليات. وللتوسع في الموقف مـن

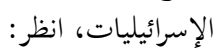

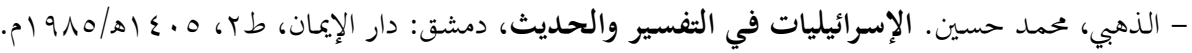

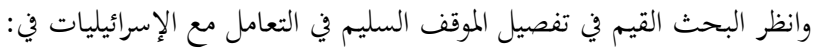

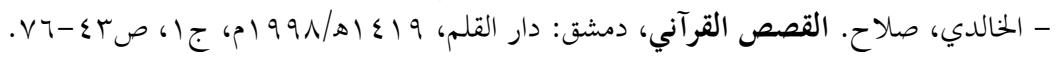

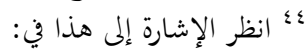
- الخالدي، القصص القرآني، مرجع سابق، جا، صوج، ـr. 
القرآن حق بألفاظه ومعانيه ومراميه، وأنه لا يصح بحال من الأحوال تأويل قصصه بالمعاني الباطلة والمواقف الباطلة في حياة الأنبياء والرسل محا ورد من أباطيل الإسرائيليات.

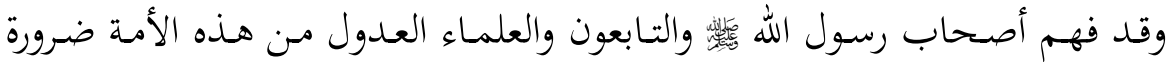

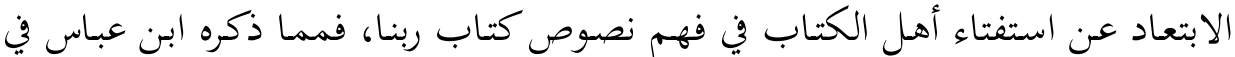

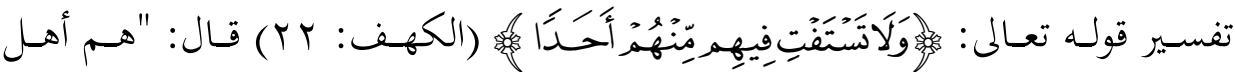

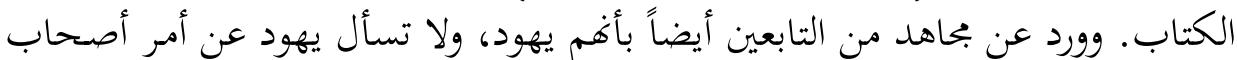

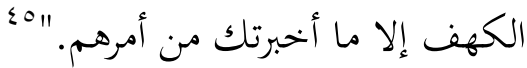

القاعـدة الثامنة: لا يمنـع هـذا كله أن بعض مقـاطع القصص القـرآني إنما جـاء ليؤكد

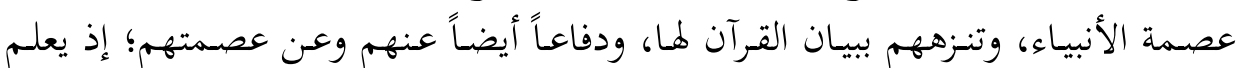

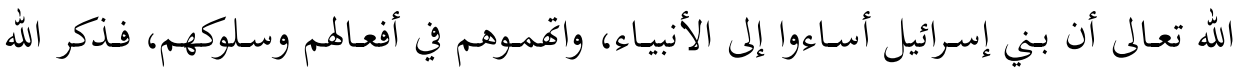

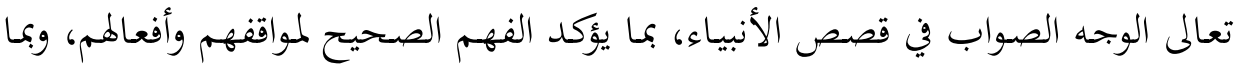

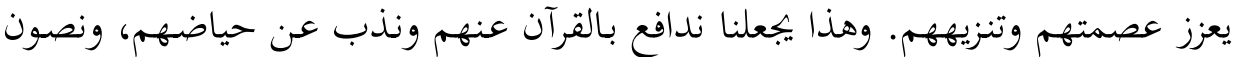

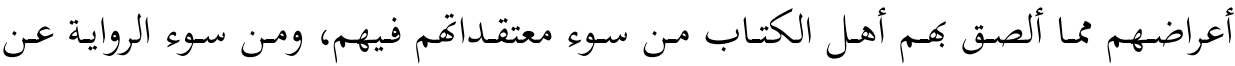
قصصهم.

وإنـه لمـن المـنهج الصـواب في زمنتـا المعاصـر انتبـاه علمائنـا في التفسـير إلى خطورة

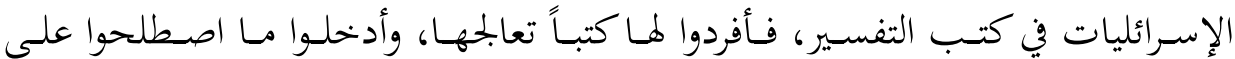
تسميته بعلم الدخيل في التفسير في جامعة الأزهر، وكليات الشريعة في العالم الإسلامي؛

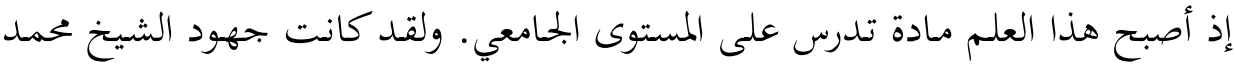

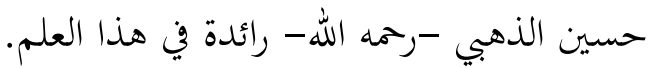

ثالثاً: إشكاليات بحث العصمة عند علماء الأشاعرة في ضوء القرآن الكريم بعد دراسة بحث العصمة وقواعدها عند أبرز علماء الأشاعرة من أهل السُّنة، والنظر في قواعد العصمة عندهم في فهم قصص الأنبياء، وبعد معرفة قواعد العصمة في القرآن

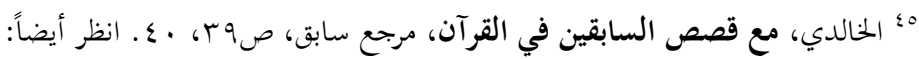

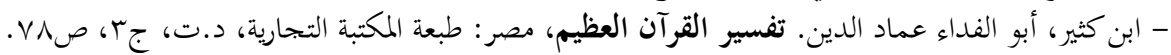

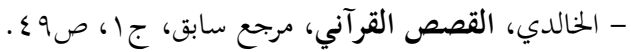




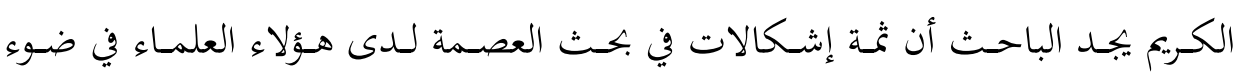
القرآن الكريم، ويمكن إجمالها فيما يأتي:

\section{1 إ إشكالية العصمة؛ وجود بحث العصمة لديهم:}

وفق نصوص القرآن وما فهمـه الصحابة، لم تكن هناك قضية اسمها العصـمة، ولم

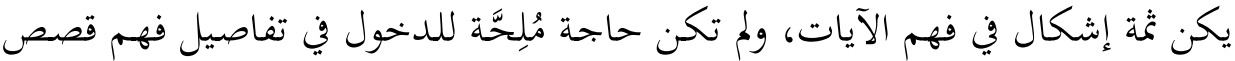

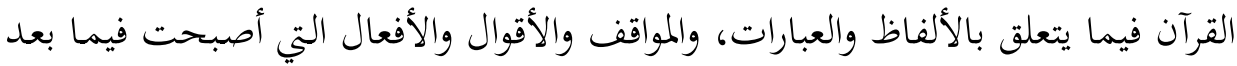

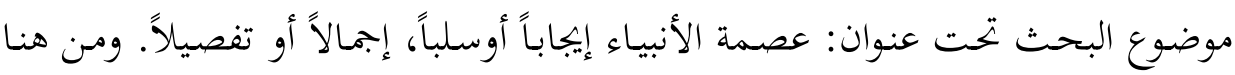

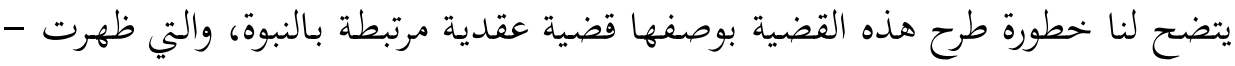

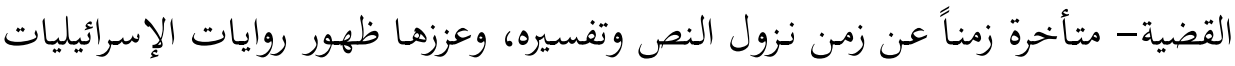

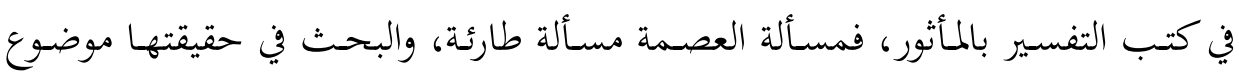

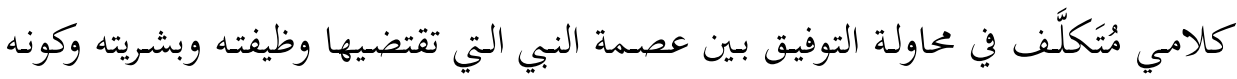

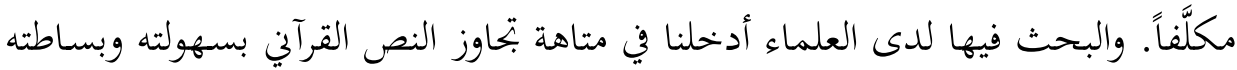

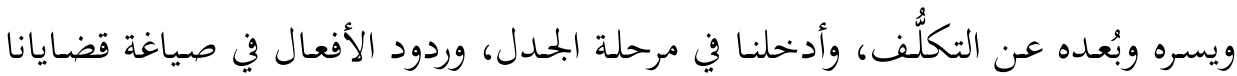

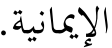

ومن ثمّ أصبحت قضية العصمة إحدى القضايا البَعْدية -أي بعد منهج الصحابة في

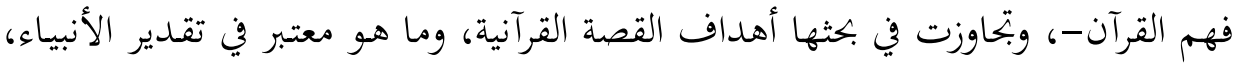

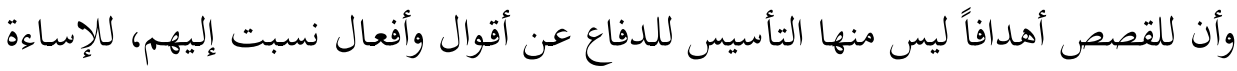

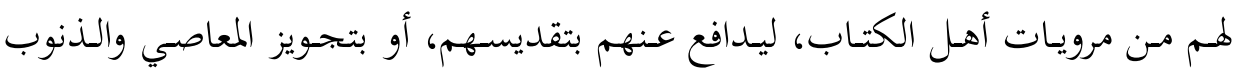

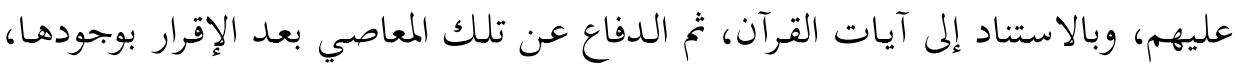

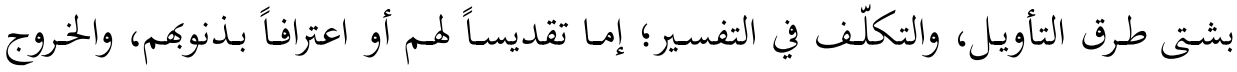

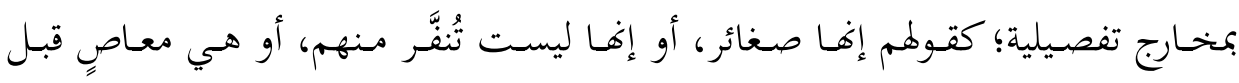

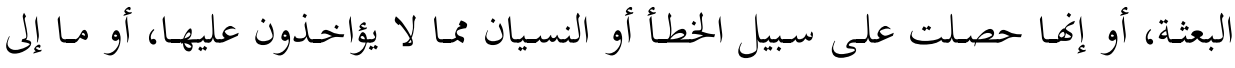

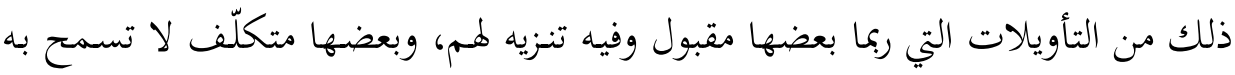

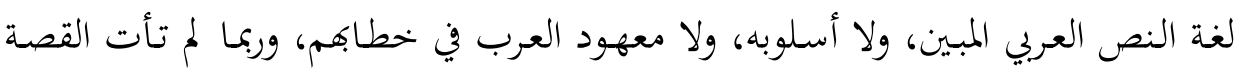


في سياقها القرآني من أجل الدفاع عن عصسمة الأنبياء أصلاً، ومما يخرجها عن الهدف

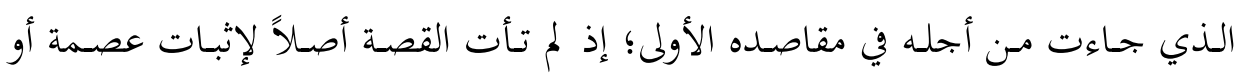
لنفيها، أو لتفسيرها، أو لطرح تأويلات لفهم ألفاظها.

\section{Y . إشكالية المصادر في قضية العصمة:}

كانت مصادر البحث في قضية العصمة لدى علماء التوحيد ثلاثة مصادر كما هو في واقع الدراسات العقدية، والتفسيرية، وهي: أولاً: قصص القـرآن بمـا لـه مـن أهـداف وفق مـنهج آيـات الله النازلـة لبيـان عقيـة النبـوة، ودور الأنبيـاء في حيـاة النـاس بمـا تناولـت مقـاطع مـن حيـاتهم، ومواقـف مـن تصرفاةهم.

ثانياً: ما ورد حول هذه الآيات من تفسير بالحمديث النبوي وما صح منه، فهو تابع في منهجه لمنهج القرآن؛ لأنه بيان له، وبتحلية لمواقفه؛ إذ لا يمكن أن يتعارض معه، لأن

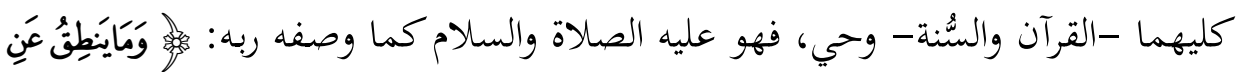

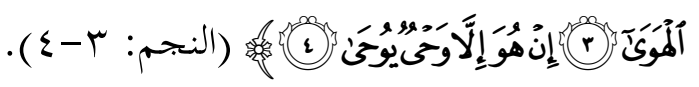
ثالثاً: ما وقع لدى العلماء الباحثين لقضية العصمة بـاختلاف فِرَرِهم، ومدارسهمه، من آراء وتفسيرات، وروايات أهل الكتاب، رواها صحابة وتابعون على أها ذات علاقة

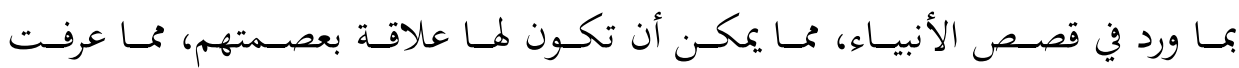

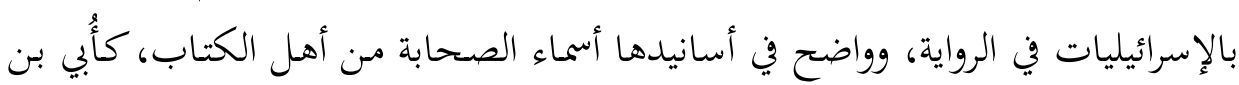
كعب، ووهب بن مُنبه وغيرهم، أو رواها تابعون مرسلةً وليست مرفوعة، أو روايات كثيرة

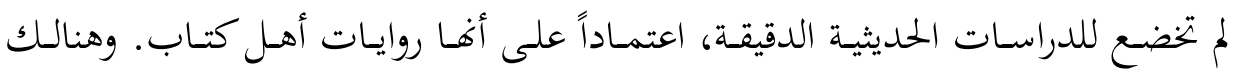
جدل بين المسلمين في الأخذ بها أو عدم الأخذ بها أو التحديث بها بلا حرج. والمشكلة في هذا المصدر الثالث فقط؛ لأن المصدرين الأولين؛ الكتاب والسّنة لا مشكلة فيهما، ولكن المشكلة هنا في كون الإسرائيليات مرجعاً لفهم القصة القرآنية، وما عند أهل الكتاب من قصص لا توقير فيها للأنبياء، ولا عصمة لهم فيها عن المعاصي؛ 


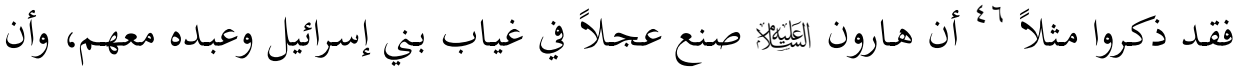

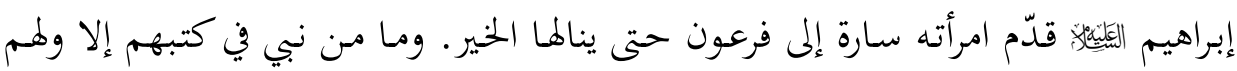
فيه قصة أو أكثر وفيها إساءة له.

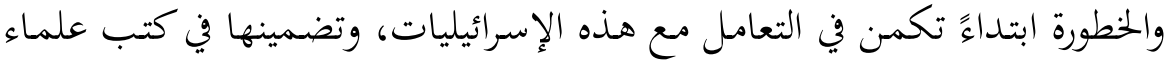

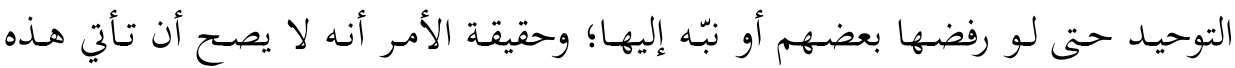

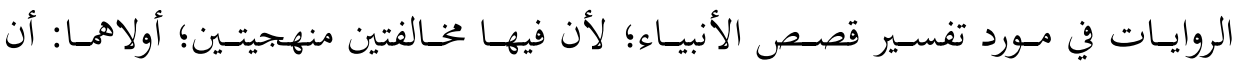

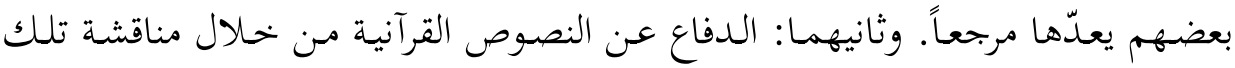

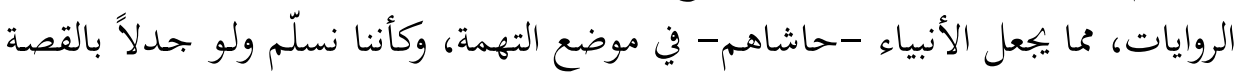

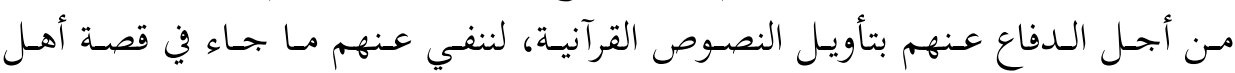

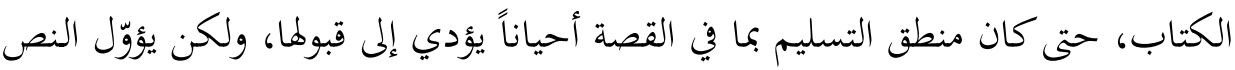
بما لا يتعارض مع عصمة الأنبياء بعد التسليم بوقوع ما جان ماءت الرعة الرواية الإسرائيلية به.

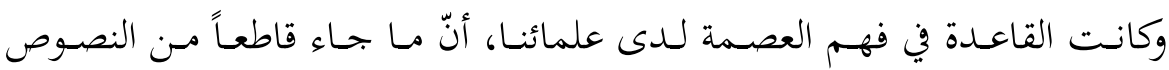

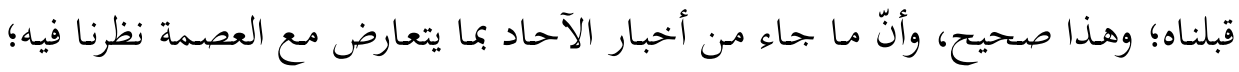

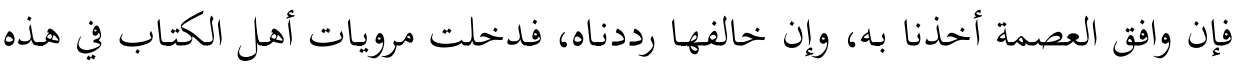

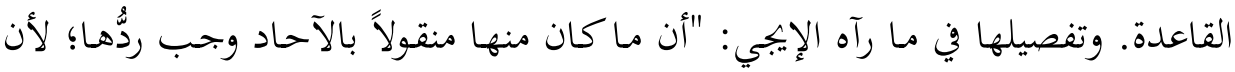

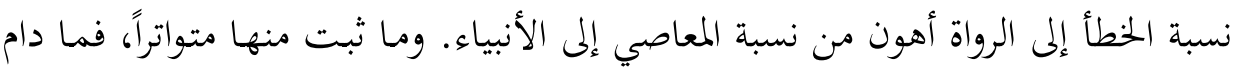

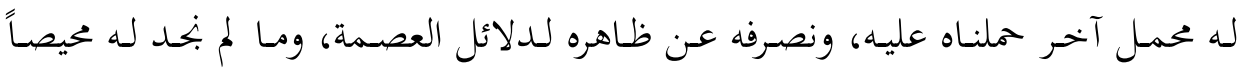

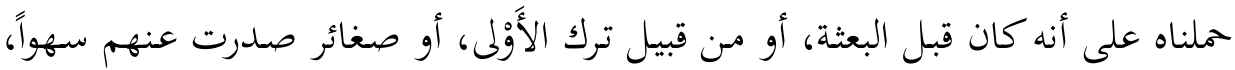

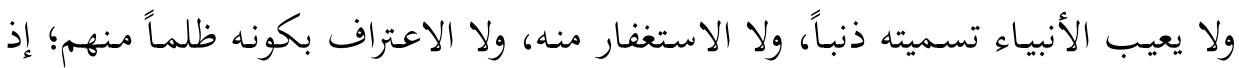

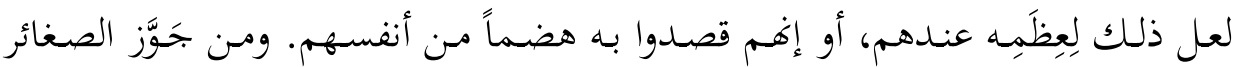
عمداً فله فسحة"

فقاعدةم هذه دعاهم إليها ورود القصص بروايات أهل الكتاب، وكلها آثار، وكان

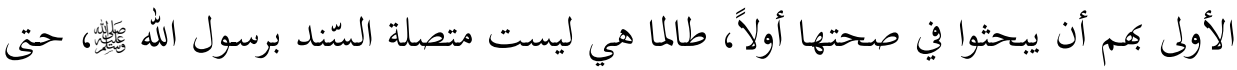

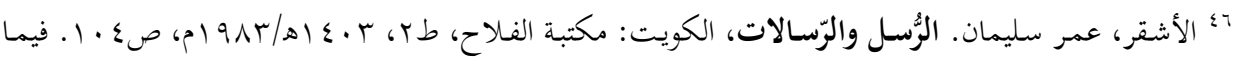

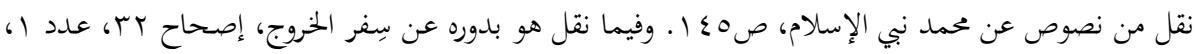


ولو كان بعضها موقوفاً على الصحابة؛ لأن حكمها حكم الإسرائيليات، ولا تشملها القاعـدة الحديثيـة أن الموقوف على الصـحابي حكمـه حكـم المرفوع؛ لأن هـذه القاعـدة

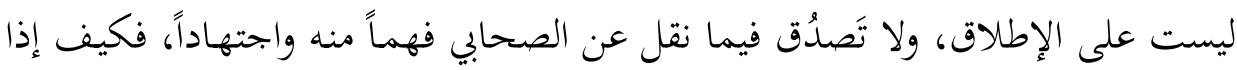
ما كان المروي تفوح منه إساءة للأنبياء فيمن وقفت الرواية عنده، وهو يهودي حتى لو أسلم، وكثير من هذه الروايات مروية عن تابعين، وانقطاع سندها عن الصحابة يجعلها غير مقبولة في الاستدلال أصلاً.

وعلى الرغم مـن هـذه القاعـدة في المرويـات لـدى العلمـاء، إلا أهـم لم يستغنوا أبـاً

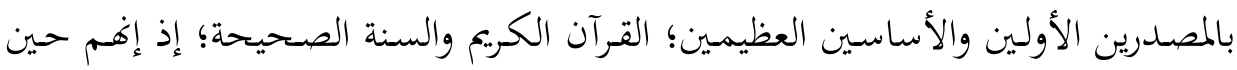

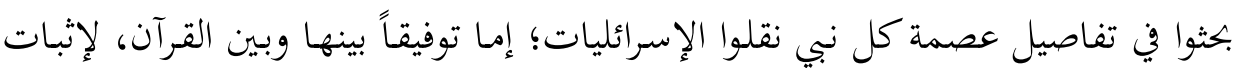
العصمة، أو لإثبات أفها لا تنافي العصمة.

أقول: فإنّ الإمام الرازي مع جلال قدره إماماً في الاعتقاد، ومفسراً بحلياً لكتاب الله عََّّلَ، إلا أن نَفَسه الطويل أدى به إلى نقل رواية الشيطان مع حواء وآدم، مع أهـا "رواية

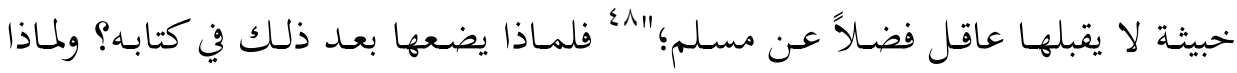
يناقشها؟ ولماذا يجعل بعض احتمالات فهمها لا يلزم فيه الكفر والفستق أصـالًّ ولماذا

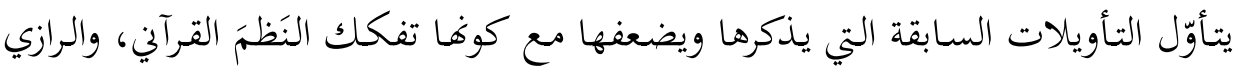

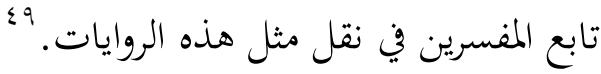

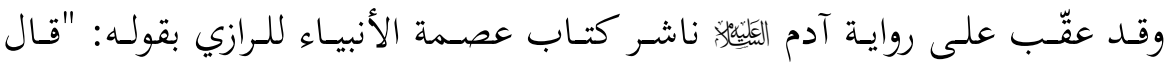

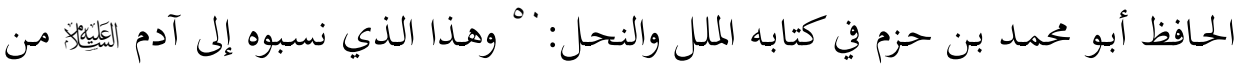
أنه سمّى ابنه عبد الحارث خرافة موضوعة مكذوبة من تأليف مَن لا دين له ولا حياء، ولم يصـح سـندها قط، وإنما نزلت الآيـة في المشركين على ظاهرهـا. والعجـب أن ابـن جرير

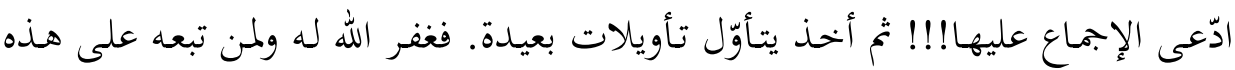

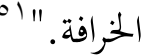

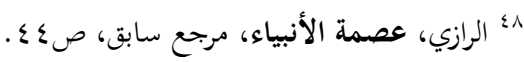

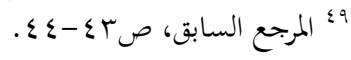
• أموالصواب أنه الفصل في الملل والنحل حتى لا يشتبه باسم كتاب الملل والنحل للشهرستاني.

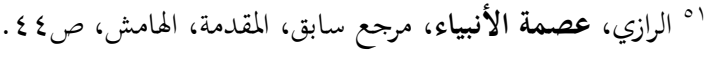




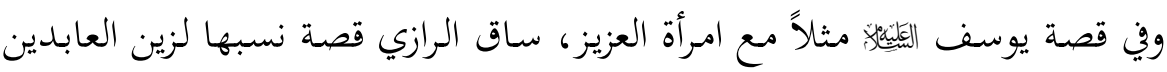

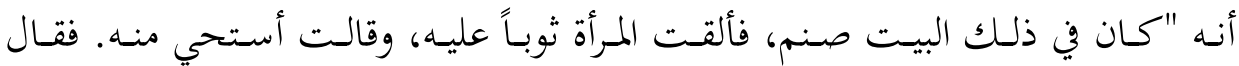

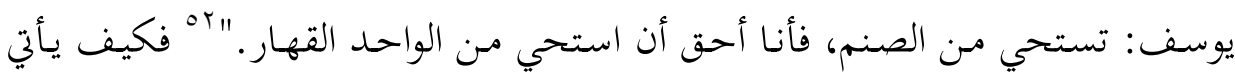

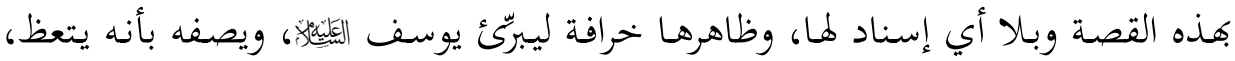

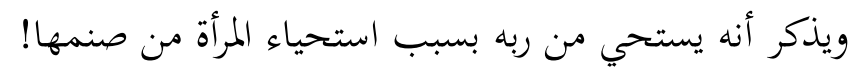

وفسّر برهان ربه الذي منعه عن الفاحشة في هذه الحادثة في الرواية، وجعلها احتمالاً

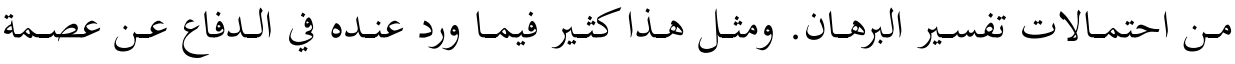
الأنبياء.

هذا الخلل في التعامل مع قصص الأنبياء لا يقبله القرآن، ولا يقبل وضعهم في قفص

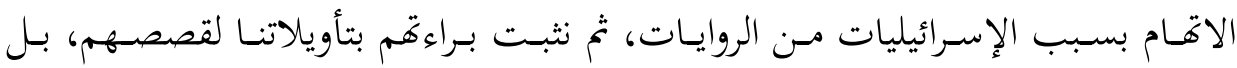

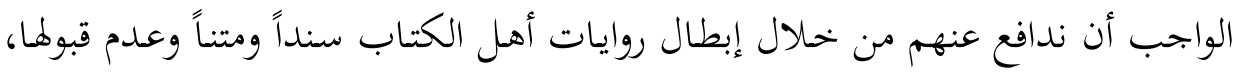

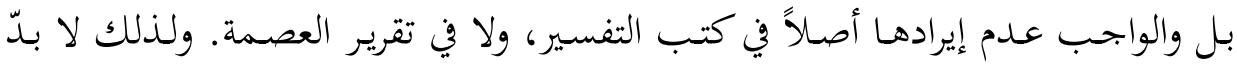

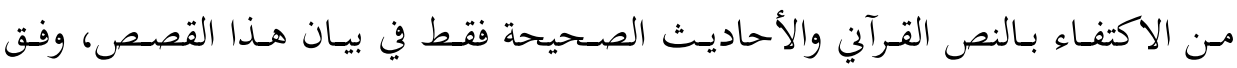

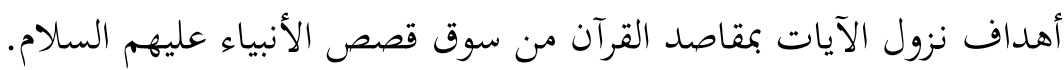

\section{r. إشكالية الدفاع عن عصمة الأنبياء:}

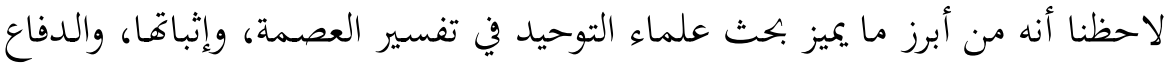

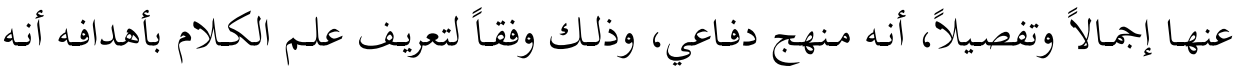

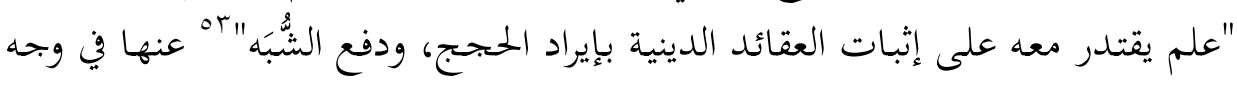

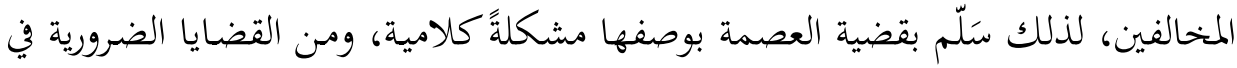

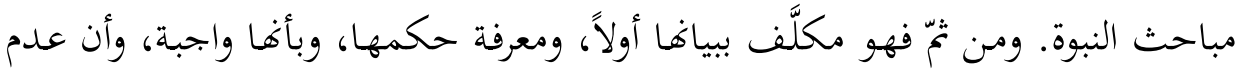

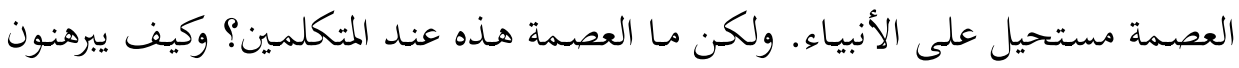

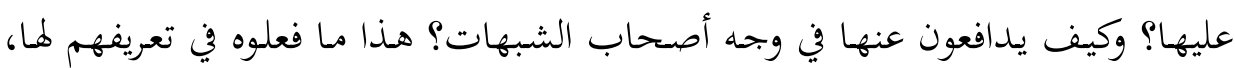

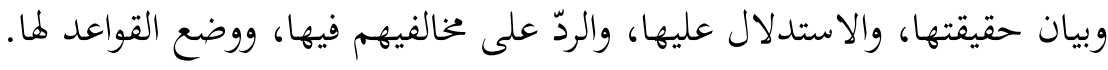

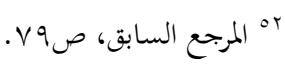
or الإييي، عضد الدين عبد الرمن بن أممد. المواقف في علم الكلام، بيروت: عالم الكتب، د.ت، صV. 
ولـذلك وقـع العلمـاء في خلــط كثـير، ودخهـول في تفاصسيل كثـيرة، وردود وأقـوال وتأويلات، وقيل وقالوا وقلنا؛ مما يجعل القارئ لهذا الفن -مـن الكتب في العقيدة أو في كتب التفسير - لا يعرف رأسه من رجليه، ولا يخرج ببهاء قراءته لكتاب الله ويَّلن، لكثرة ما تشوش فكره بين قائل وبحيب ومعترض وسائل، وبين زاعم للشُّبهة، ورادّ عليها. ومن ثمّ، فإن بكثهم للعصمة كان ينفع في إطار الدراسات البحثية والجحلية في تاريخ

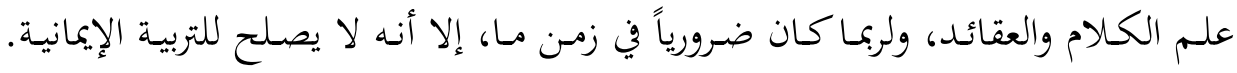

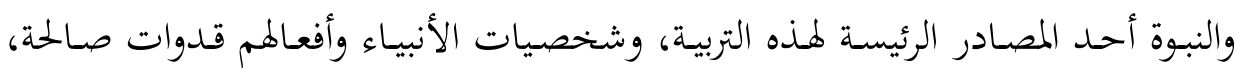
وهدايات ومنارات تدعو المؤمنين للتأسي والاقتداء بها. ومن هنا فبإن بحث العصمة لدى علماء التوحيد، والجهود المبذولة فيه بحثُ دفاعي أكثر من كونه بحثاً إيجابياً في التربية.

\section{ع ـ إشكالية الفهم والثأويل:}

إن من أشد الأمور غرابة في فهم آيات قصص الأنبياء، ما وقع في كتب التفسير أوّلاً من التسليم بالمرويات بوصفها أولى الخطوات في فهم الآيات، وكوها مأثوراً؛ لأن المأثور يُقتدم على الرأي في التفسير، فيجعلون تلك الروايات هادياً لهم في فهم الآيات، رادّين فَهْم الألفاظ في المغفرة، والتوبة، والإنابة، والمعصية، والظلم إلى ما وقع في الإسرائيليات.

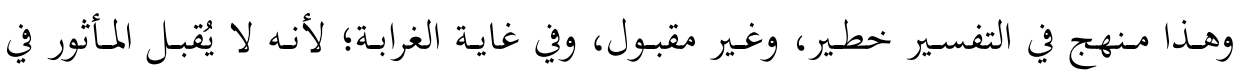

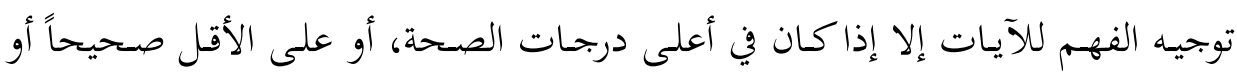
مقبولاً شرعاً وعقلاً إن لم يكن متواتراً؛ لأنه تفسير لنص قطعي في ثبوته وهو القرآن، وقد إند

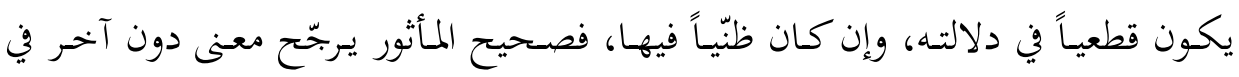

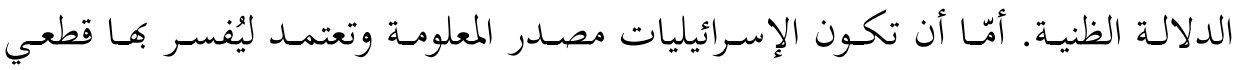
الثبوت، حتى مع ظاهرية المعنى في اللفظ إلى ما يتجاوب مع الرواية الإسرائيلية؛ فهذا أمر خطير غير مقبول في فهم قصص القرآن الكريم.

وقـد كـان تفسير الطبري مليئاً بهـذا، وتبعهه بعـد ذلك كل مـن أخهـ عنـه مـن أهـل التفسير بالمأثور كابن كثير، وإن تميّز عنه بأنه كان يُنبّه على بعض الإسرائيليات، ثم نقل

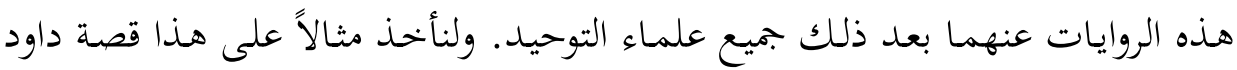




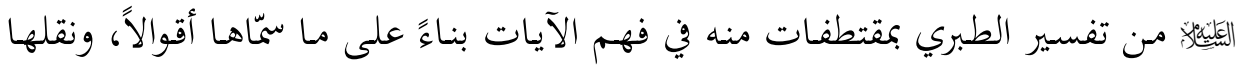

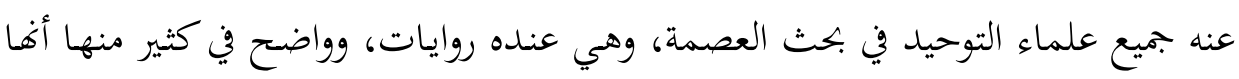

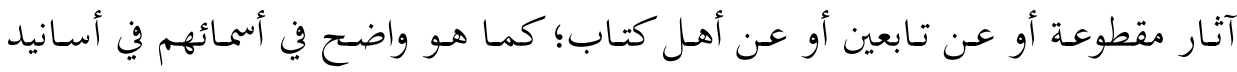
تلك الروايات، ومنهم على سبيل المثال لا الحصر وهب بن منبّه.

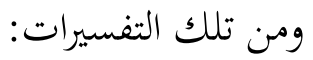

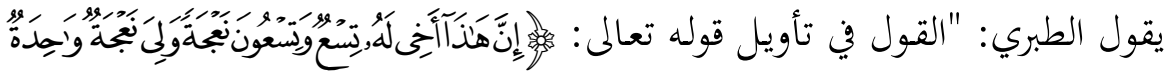

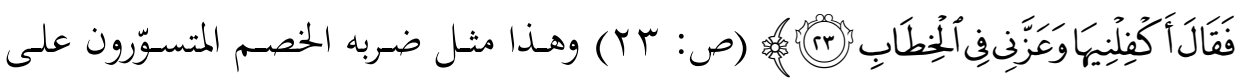

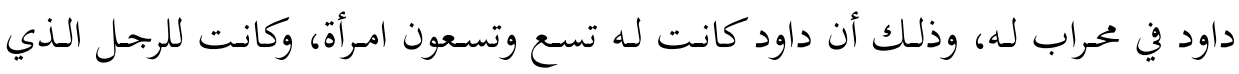

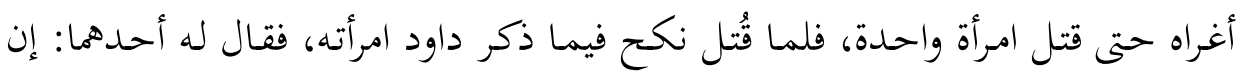

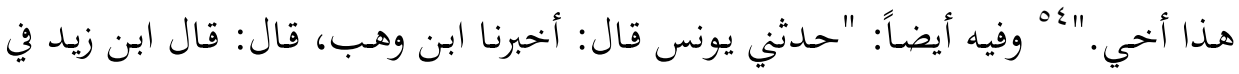

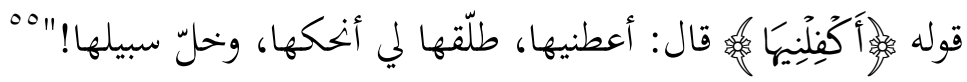
ولذلك فسّر النعجة بالمرأة بحاوباً مع هذه الروايات المسيئة للنبي داود، خلافاً للتعامل

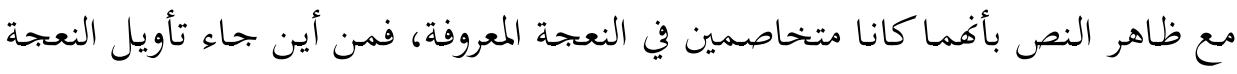

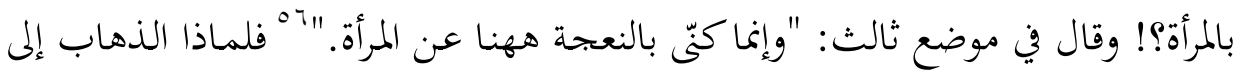

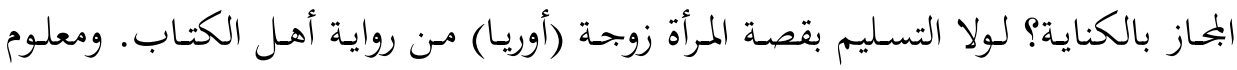

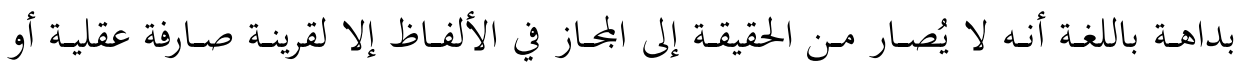

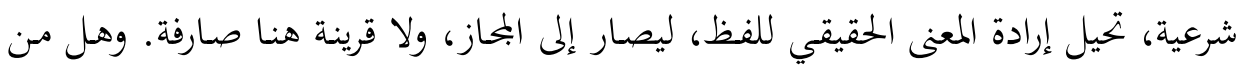

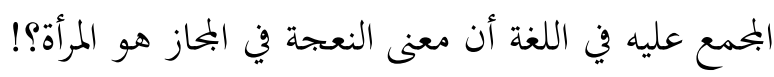

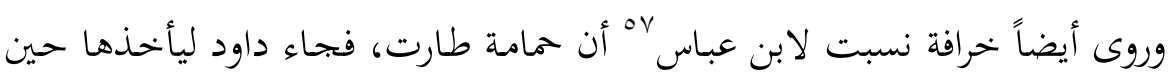

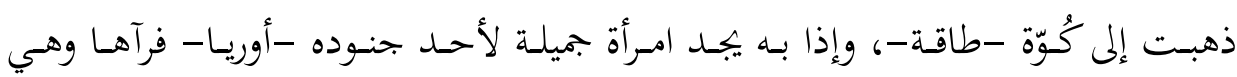

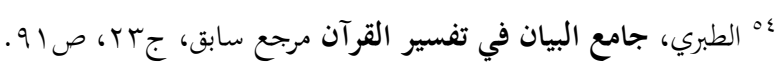

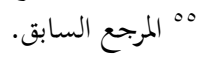

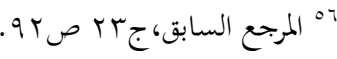
ro تخيل مثل هذا الإسناد: حدثني أبي عن عمي قال عن أبي عن أبيه. فهو إسناد معيب في الصنعة الحديثية 
تغتسل، فأرسل إليها وطلب أن يتزوجها، فأخبرته أها لا تخون زوجها، فأمر قائد سرية

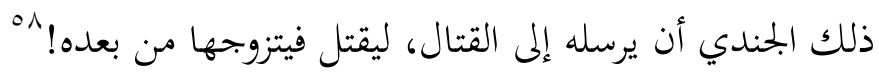

فلنتخيل كيف تروى قصص من هذا النوع في تفسير آيات الله، وهي قصة لا تُقبل من سفلة الناس، فضلاً عن أنبياء الله ورسله عليهم الصلاة والسلام. وحتى تأويل الخصمين بأفما ملكان من أجل استكمال حلقات القصة الإسرائيلية،

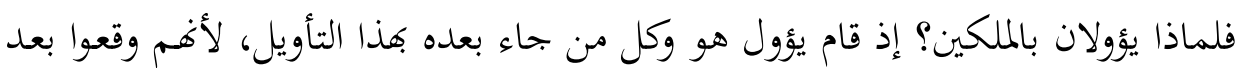

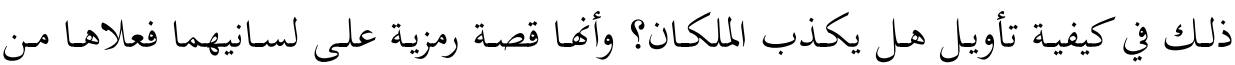

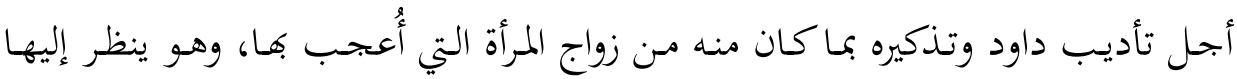

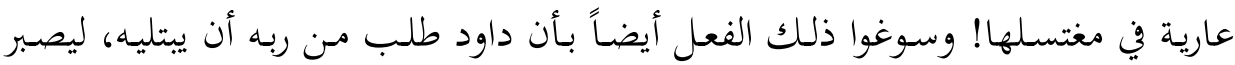

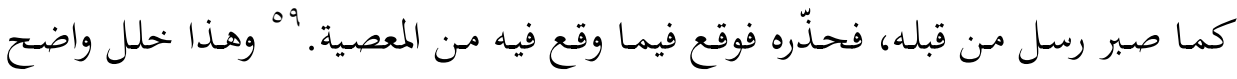

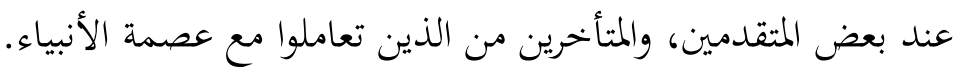
مـا هذا النسيج القصصي مـن روايات بني إسرائيل التي تُعتمد، لتُذهِب بهاء تفسير

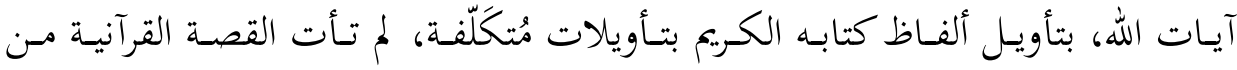

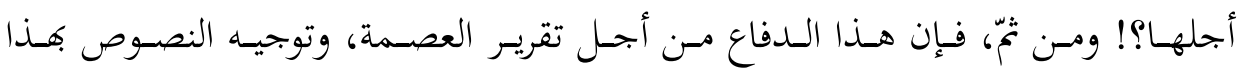
الأسلوب قد ضيّع العبرة من قصص الأنبياء.

وحقيقة الأمر: أنه لا بدّ أن تفهم الألفاظ بمعانيها في لغة النص، بلسان عربي مبين،

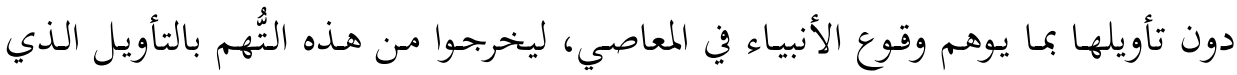

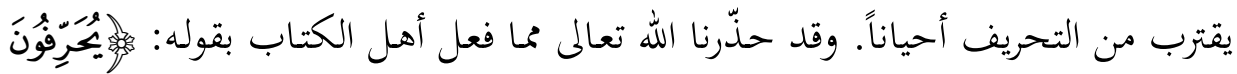

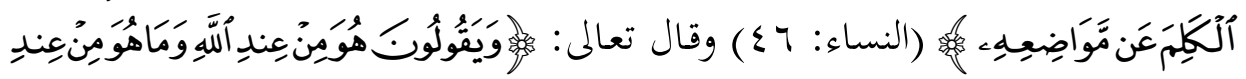

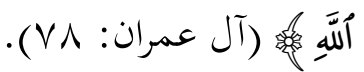

وأخحيراً، فبإن بحـاوز قواعد القرآن في فهم النصوص مـن خهلال سياقاتما، هو الذي أوقع المفسرين، والمتكلمين، وسائر من بحث في العصمة في هذا المنزلق، وهو ما عبرنا عنه بإشكالية فهم النص وتأويله.

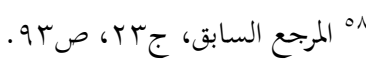

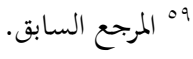




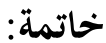

قصدت هذه الدراسة إلى إعادة النظر في بحث عصمة الأنبياء بعد أن خحاض فيه

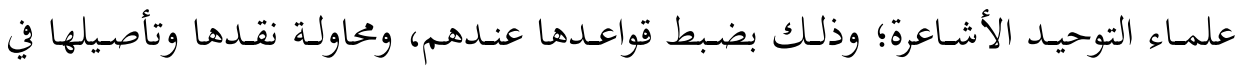

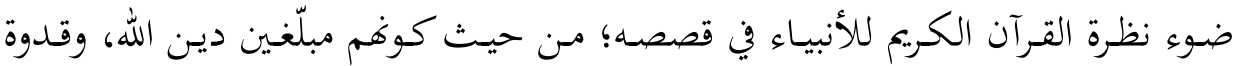

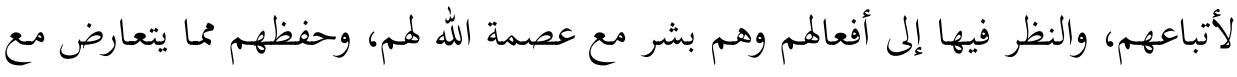

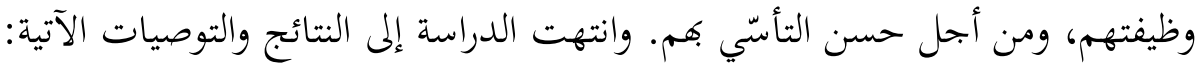

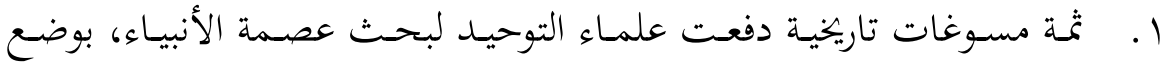

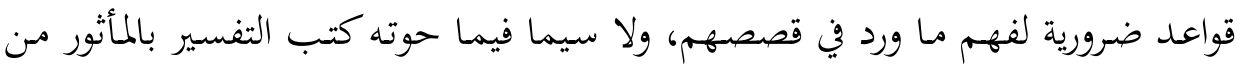

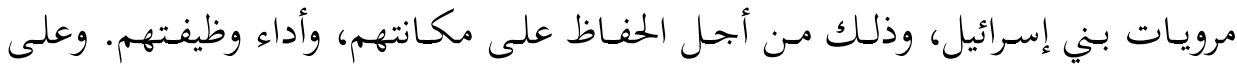

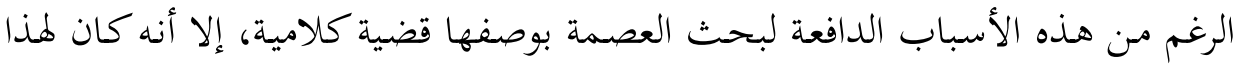

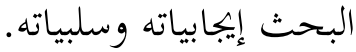

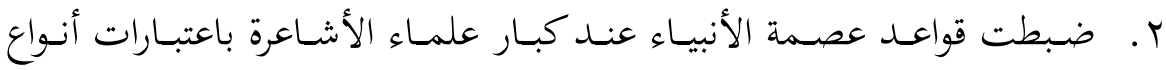

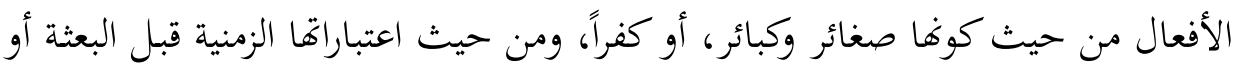
بعدها، ومن حيث إرادقهم؛ عمداً أو نسياناً. ץ. حاولت الدراسة تقديم قراءة تأصيلية جديدة لبحث العصمة، باستنباط قواعد

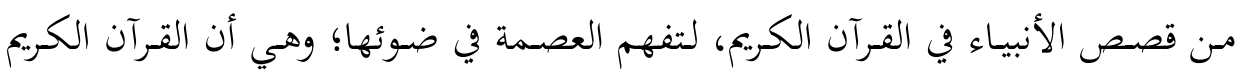

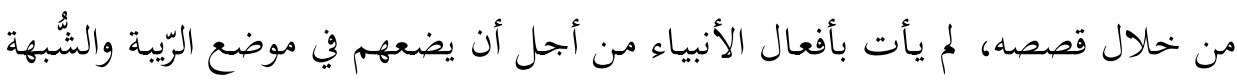

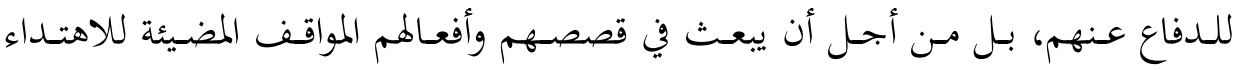

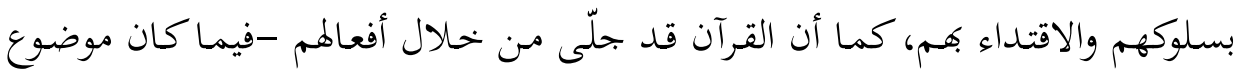

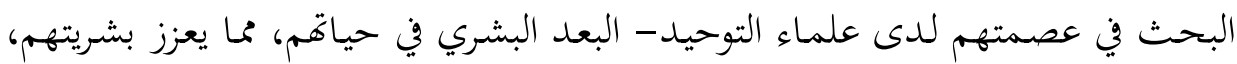

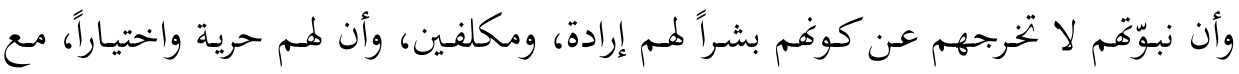

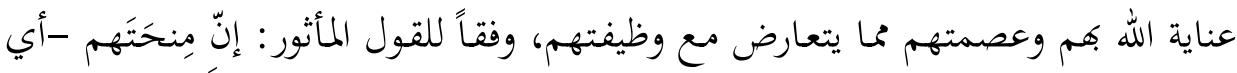

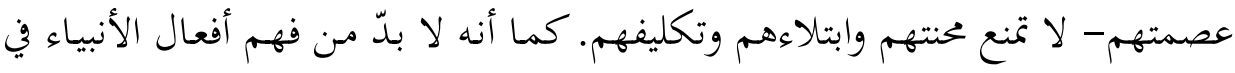

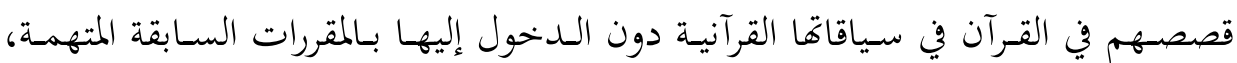




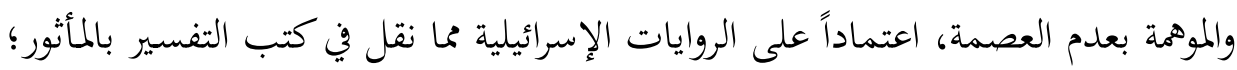

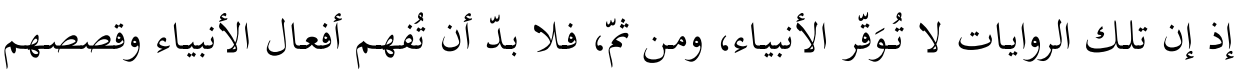

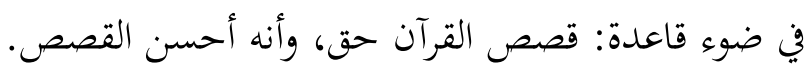

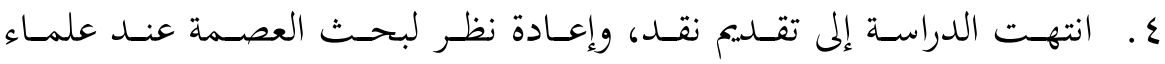

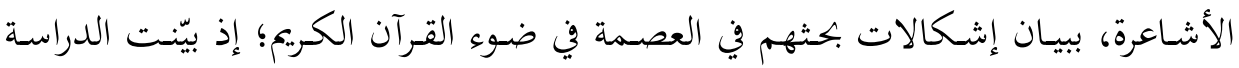

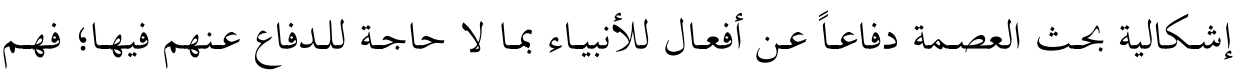
ليسوا موضع عَمة، ولا شكُّ أصلاً.

ه. كما بيّنت الدراسة إشكال مصادر علماء التوحيد في دفاعهم عن عصـمة

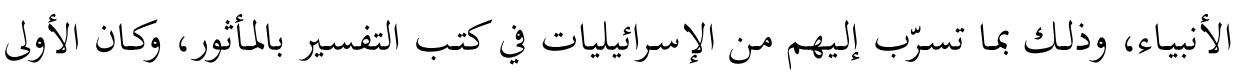

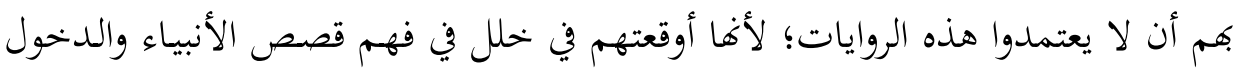
في معركة الدفاع عن عصمتهم.

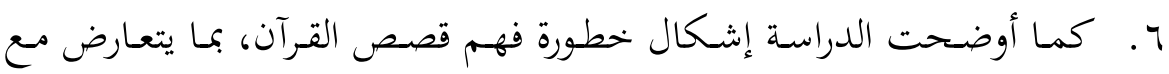

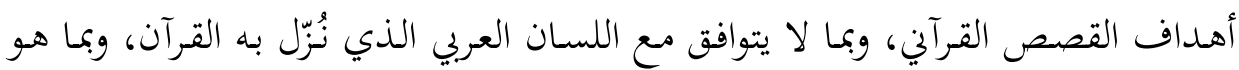

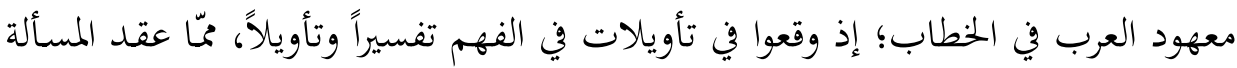
وأخرجها عن سياقها الإيماني، والتربوي.

V. وأخيراً، يوصي الباحث، استكمالاً لمذه الدراسة، بضرورة بناء دراسة تفصيلية

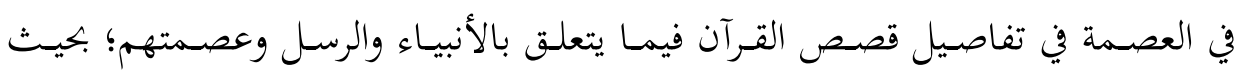

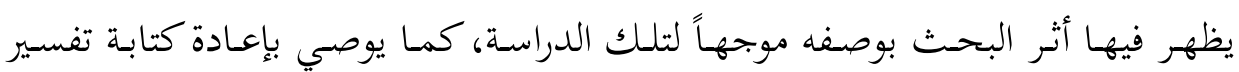

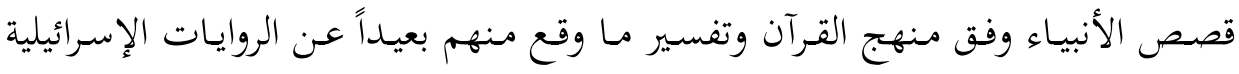

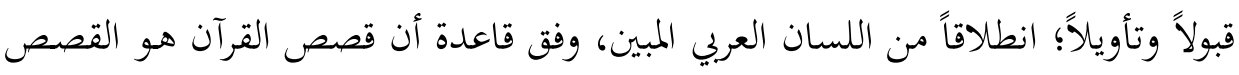

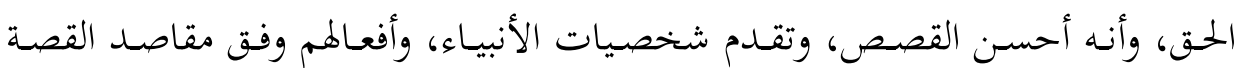

